\title{
Head Start Participation ANd Childhood Obesity
}

by

David Frisvold

Faculty Sponsor: James Foster

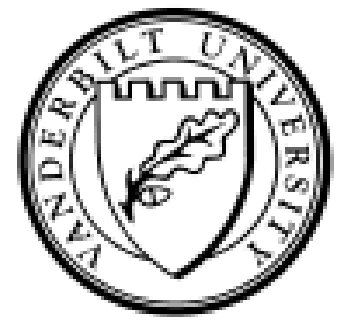

Working Paper No. 06-WG01

February 2006

\section{DEPARTMENT OF ECONOMICS \\ VANDERBILT UNIVERSITY \\ NASHVILLE, TN 37235}

www.vanderbilt.edu/econ 


\title{
Head Start Participation and Childhood Obesity
}

\author{
David Frisvold \\ Vanderbilt University
}

February 19, 2006

Abstract: Childhood obesity is a significant public health problem that also has economic consequences. Medical research suggests that nutritional interventions at a young age can influence nutritional behavior and reduce childhood obesity. This paper estimates the impact of one such intervention - Head Start - on childhood overweight and obesity. While Head Start is more commonly known as an educational intervention, a large part of the program includes nutrition services and nutritional education to parents and children. For black children, Head Start participation is shown to significantly reduce the likelihood of being overweight or obese.

JEL Classification: I12, I38, H53, J13

$\underline{\text { Keywords: }}$ obesity, Head Start, health, early childhood education

Correspondence: David Frisvold, Department of Economics, Vanderbilt University, VU Station B \#351819, 2301 Vanderbilt Place, Nashville, TN 37235; Tel.: 1615322 2871; Fax: 1615343 8495; E-mail: david.e.frisvold@vanderbilt.edu.

Acknowledgements: I thank Kathryn Anderson, Dale Ballou, William Collins, James Foster, Robert Margo, and seminar participations at Baylor University, the CNA Corporation, the Government Accountability Office, and University of North Carolina at Greensboro for helpful suggestions. I also thank Nicole Harmon at Xtria for providing me with access to the Head Start Program Information Report data and Ashley Crownover for editorial assistance. Financial assistance from the National Institute for Child Health and Human Development (Grant No. 1 R03 HD045547-01A1) and the Household International Research Support program is gratefully acknowledged. 


\section{Introduction}

The prevalence of childhood obesity in the United States has risen dramatically in the last thirty years, doubling for children ages 6 to 11 and tripling for children ages 12 to 17 (Dietz, 2004). This increase is a concern for public health officials due to the association between childhood obesity and a myriad of health consequences, such as hypertension and other cardiovascular disease risk factors, type 2 diabetes, sleep apnea, and asthma (Ebbeling, Pawlak, and Ludwig, 2002). Additionally, childhood obesity is a significant determinant of adult obesity (Whitaker et al, 1997), and adult obesity is linked to an increased risk of various comorbidities (Office of the Surgeon General, 2001, table 1) and premature death (Fontaine et al, 2003; Peeters et al, 2003).

According to Cutler, Glaeser, and Shapiro (2003), the recent rise in obesity is the result of an increase in the amount of calories consumed, not a decrease in the amount of calories expended. Caloric intake has increased because the cost of food preparation has gone down. The technological innovations that led to decreases in food prices were welfare-enhancing for most of the population, but not for individuals with limited self-control. These individuals would prefer to weigh less than they do, but are not able to realize their ideal weight. For such individuals, the cost of obesity is high, as evidenced by the $\$ 30$ to $\$ 50$ billion spent annually on dieting (Cutler, Glaeser, and Shapiro, 2003).

The private costs of obesity are not restricted to dieting expenses. White females suffer a wage penalty as a result of obesity that is equivalent to approximately one and a half years of schooling or three years of experience (Cawley, 2000). Additionally, obese white women have lower family incomes, mainly resulting from a lower probability of marriage and lower spouse’s earnings (Averett and Korenman, 1993). 
The social costs of obesity are extensive; in 2000, these costs were estimated at $\$ 117$ billion (Office of the Surgeon General, 2001). This figure is composed of $\$ 61$ billion in direct costs associated with preventive, diagnostic, and treatment services for obesity, and $\$ 56$ billion in indirect costs consisting of the value of lost productivity from illness due to obesity, and the value of lost future productivity from premature death. These costs mainly result from type 2 diabetes, coronary heart disease, and hypertension - comorbidities associated with childhood obesity (Wolf, 1998).

Given that childhood obesity leads to adult obesity, that the social costs of adult obesity are driven by diseases linked to childhood obesity, and that social investments in young children are generally more productive than similar investments in adults (Heckman and Masterov, 2004), social programs targeted towards children may be the most effective public policies in reducing obesity and increasing social welfare. Grossman's (1972) health capital model reiterates this idea - health is determined cumulatively, and early childhood investments in health can have a lasting impact. As described in Healthy People 2010, establishing behaviors that prevent obesity - healthful dietary and physical activity behaviors - should begin in childhood (U.S. Department of Health and Human Services, 2000).

To combat the rise in childhood obesity, many public health officials and researchers have advocated for reforms in the public school system (e.g., Office of the Surgeon General, 2001; James et al, 2004; Dietz and Gortmaker, 2001). However, the increase in childhood obesity is evident in children as young as 4 years old (Ogden et al, 1997). Early prevention activities during the preschool years may, in fact, be the most effective (Davis and Christoffel, 1994). This period of time is influential in determining behavior patterns associated with diet and physical activity (Birch, 1999). Dietary intake and physical activity of preschoolers can 
account for more of the variance in body mass index than whether or not a young child's parents are obese (Klesges et al, 1995). To prevent childhood obesity, Deckelbaum and Williams (2004) suggest that preschool programs provide children with exposure to a variety of foods and flavors, assist in the development of healthy food preferences, encourage appropriate parental feeding practices, monitor the weight of children, and provide child and parent nutritional education. Head Start, the early childhood development program targeted towards disadvantaged youths, is an example of one such program.

As the cornerstone of President Lyndon Johnson’s “War on Poverty,” Head Start provides a comprehensive array of services to poor and disabled children to better prepare them for subsequent educational experiences. Even though the overall goal is educational, Head Start's planning committee designed the program with a variety of development services believing that nutrition, physical and mental health, parental involvement, and social services in conjunction with early childhood education - would contribute to the educational development of participants far more than offering strictly academic instruction. Because of the program’s overall goal, most evaluations have focused on educational outcomes; however, based on the menu of services offered, it is reasonable to expect that additional outcomes are influenced by Head Start participation. In particular, Head Start provides nutritious meals that encourage children to try a variety of foods, screens children for nutritional deficiencies and obesity, and emphasizes nutritional education, both for children and for parents. Based on these components of the program and the timing of these services at a critical point in child development, Head Start participation may impact childhood obesity. 
Previous research on the efficacy of school-based intervention programs has demonstrated that it is possible to reduce the prevalence of childhood obesity. ${ }^{1}$ However, these programs often serve older children than Head Start, offer less comprehensive nutritional services, and do not target disadvantaged children who are at a higher risk of childhood obesity. It is possible then that Head Start, a program not specifically designed to prevent childhood obesity, could result in larger benefits than obesity intervention programs.

This paper estimates the impact of Head Start participation on childhood overweight and obesity using data from the Panel Study of Income Dynamics and its Child Development Supplement. The key advantages of these data are that height and weight for children are measured, not self-reported, and that family background characteristics, including parents’ height and weight, are available prior to Head Start attendance.

The difficulty that arises in examining the effect of Head Start participation is that selection into Head Start is the result of choices made by parents and administrators. The determinants of these choices may be related to the future outcomes of Head Start participants and, thus, simple estimators such as OLS may lead to inconsistent estimates of the impact of Head Start participation. To overcome this problem, an instrumental variables approach is implemented. Because the outcome variables - overweight and obese - are binary and the endogenous variable - Head Start participation - is binary, a bivariate probit model is estimated.

\footnotetext{
${ }^{1}$ Story (1999), in a review of school-based obesity treatment programs, finds that these interventions reduce the prevalence of childhood obesity by 10 percentage points, on average, and that these effects are generally larger for younger children. However, these programs were mostly conducted prior to 1985 when the prevalence of obesity was lower than it is today. Gortmaker et al (1999) finds that a middle-school intervention that targets behavioral modification through child education reduced the probability of being obese by roughly five percentage points. Veugelers and Fitzgerald (2005) report that a two and a half year intensive program that began in fifth grade that involved children and their families, emphasized daily physical activity, provided nutritious meals, and promoted nutritional education reduced the probability of being obese by approximately six percentage points. Because this intervention occurred in Canada, which has lower obesity rates than the United States, this intervention decreased the prevalence of childhood obesity by approximately 50 percent. All of these interventions were population-based in the since that these programs served all students at the school and the schools were not selected because they were located in community with a high prevalence of obesity.
} 
This framework allows for the unobserved determinants of overweight and obesity to be correlated with the unobserved determinants of Head Start participation. The impact of participating in Head Start is identified from an exclusion restriction based on program availability; variation in the relative availability of Head Start, as measured by the number of available slots per eligible child in the local community, influences Head Start participation, but does not directly affect overweight and obesity.

After selection into Head Start is accounted for, the results suggest that Head Start significantly reduces the probability that a participant will be overweight in later childhood. This result is driven by the impact of Head Start for black participants; black children are less likely to be overweight and less likely to be obese as a result of Head Start. Given the health and economic consequences of obesity, these results demonstrate that participation in Head Start can improve the lives of disadvantaged youths and social welfare in ways not previously established.

\section{Background on Head Start}

Head Start is a comprehensive, national, federally funded program designed to augment the human and health capital of disadvantaged children to better prepare them for subsequent educational experiences. Since its inception in 1965, Head Start has provided services to more than 22 million preschool children (Head Start Bureau, 2005). In 2004, 905,851 children attended Head Start at an average cost of \$7,222 per child. Fifty-two percent of these children were 4 years old and 34 percent were 3 years old. Thirty-one percent of Head Start participants in 2004 were black, 31 percent were Hispanic, and 27 percent were white (Head Start Bureau, 2005). 
Head Start is currently administered through the Head Start Bureau in the Administration for Children and Families (ACF) of the Department of Health and Human Services. Head Start appropriations, determined annually as a component of the federal budget, are earmarked for states based on the number of children less than 5 years of age in families with incomes below the poverty line. Based on the allotment of funding across states, Head Start funds are directly provided to local Head Start programs that are awarded grants by the ACF. Grants are awarded to agencies that are able to demonstrate the most cost-effective program with qualified and experienced staff that will adhere to the Head Start Performance Standards, provided that there is a sufficient need for Head Start services in the community (Head Start Bureau, 2004). While grants are awarded for only three years, previously funded agencies are given funding priority. Each grantee must contribute 20 percent of the total costs; however, this requirement can be satisfied from in-kind donations through community partnerships. Head Start programs are operated through community development agencies, local school districts, private organizations, and Indian Tribes. There were 1,604 grantees that operated 20,050 centers with 48,260 classrooms in 2004 (Head Start Bureau, 2005).

Eligibility for Head Start participation is determined primarily by family income; a child is eligible if the family's gross annual income, including unemployment compensation and other sources of transfer income, is less than or equal to the poverty line (Head Start Bureau, 2004). A child in a family whose income exceeds the poverty line is eligible for Head Start if the family receives public assistance, if the child is in foster care, or if the child is disabled. Additionally, a child must be at least 3 years old to be eligible for Head Start participation, based on the date used by the community to determine public school eligibility. Once enrolled in Head Start, 
children may remain in the program until kindergarten or first grade is available in the community, provided that they continue to meet the Head Start eligibility criteria.

The service area for each Head Start program is defined in its Head Start grant application as either a county or sub-county area (e.g., census tract) - with the exception of rural programs, which often serve multiple counties - and is approved by the Department of Health and Human Services to ensure that the service area does not overlap with other Head Start programs (Head Start Bureau, 2004). Within the service area, each Head Start program must actively recruit and inform as many families with eligible children as possible. To ensure that programs are recruiting as many children as possible, the number of applications for each program must exceed the expected enrollment.

Each Head Start program must establish a formal selection mechanism for determining which eligible children are admitted into the program. At least 90 percent of participants must come from families with incomes below the poverty line, and at least 10 percent of the enrollment opportunities must be available for children with disabilities. Additionally, children with the greatest need for Head Start services should be selected by the program administrators. This ensures that children in families with incomes farthest below the poverty line are most likely to be chosen to enroll in the program, as well as children with more severe disabilities. Children without two parents are more likely to be selected into the program than children from two parent families. Also, children in high risk families are preferentially admitted into the program. Although high risk may be defined differently across programs, this category can include children in families with substance abuse or domestic violence; children in families afflicted by a crisis such as death, separation, terminal illness, or chronic health issues; children referred into Head Start by a community agency; or other special circumstances. 
Head Start provides comprehensive child development services to achieve the program's overall goal of improved school readiness. To enhance participants' cognitive skills, Head Start centers implement a curriculum that emphasizes age-appropriate literacy, numeracy, reasoning, problem-solving, and decision-making skills (Head Start Bureau, 2004). Parents are encouraged to assist in creating the center's curriculum and an individualized developmental strategy for their child. Continual assessments are conducted by the program staff to promote each child's progress.

Head Start, however, offers more than simply cognitive activities to increase participants' human capital. For example, Head Start's federal guidelines emphasize nutritional health as an essential component of child development. Nutrition services are provided because malnutrition can dampen educational growth, and nutritional problems - such as iron deficiency anemia - are often associated with poverty. Increasing nutrition can lead to cognitive improvements and greater educational attainment (Maluccio et al, 2005).

The nutritional aspects of Head Start's services include nutritional screening, providing healthy meals, and nutritional education. Head Start personnel determine the child's nutritional needs through nutritional assessments (height, weight, and hemoglobin/hematocrit testing) and from information about the child's and family's eating habits, and then design and implement a nutritional plan. At the beginning of each day, children who have not received breakfast prior to their arrival at a Head Start center are provided a nutritious breakfast. Children in a full-day program receive meals and snacks that provide one-half to two-thirds of their daily nutritional needs. Meal times provide the opportunity for nutritional education and children are encouraged to try a variety of foods. These Head Start guidelines are consistent with the recommendations of the American Dietetic Association (Briley and Roberts-Gray, 1999). Parents also receive 
training, through classes and informal discussion, on food preparation and nutrition. This helps them improve the nutritional content of the food consumed by Head Start participants and helps children develop sound nutritional habits. Parental education carries over to the home; Head Start parents frequently report discussing good nutrition and healthy foods at home with their child (Keane et al, 1996).

The services provided by Head Start have generally been successful in increasing children's educational outcomes. Head Start participation leads to short-term cognitive benefits (McKey et al, 1985; Currie and Thomas, 1995; U.S. Department of Health and Human Services, 2005) that persist for white, but not black, participants (Currie and Thomas, 1995). Perhaps because of improvements in non-cognitive skills (e.g. Heckman, 1999; Blau and Currie, forthcoming), Head Start leads to sizeable longer-term educational benefits. However, these benefits accrue for whites, but not blacks. Head Start participants are 40 percentage points less likely to be held back a grade in school (Currie and Thomas, 1995), are 22 percentage points more likely to graduate high school (Garces, Thomas, and Currie, 2002)., and are 19 percentage points more likely to attend college(Garces, Thomas, and Currie, 2002) in comparison to other preschool participants.

Head Start participation also results in health and social benefits, although these outcomes have received less attention in the literature than cognitive and educational outcomes. Participants are more likely to receive age-appropriate health screenings or dental examinations (Hale, Seitz, and Zigler, 1990; U.S. Department of Health and Human Services, 2005) and are 8 percentage points more likely to be immunized for measles than children who did not attend any form of preschool (Currie and Thomas, 1995). Head Start participation is also associated with a 33 to 75 percent reduction in child mortality rates (Ludwig and Miller, 2005). Additionally, 
Head Start participants are 17 percentage points less likely to smoke cigarettes as young adults than other preschool participants (Anderson, Foster, and Frisvold, 2004). Black Head Start participants are 12 percentage points less likely to be arrested for or charged with a crime than other preschool participants (Garces, Thomas, and Currie, 2002). Descriptive evidence, provided by parents, suggests that children and parents improve their nutritional behaviors as a result of Head Start attendance (Keane et al, 1996). These outcomes from Head Start participation suggest that the comprehensive services provided to increase the educational opportunities of disadvantaged children also lead to comprehensive benefits. In particular, it is likely that exposure to the services of Head Start, including nutrition and nutritional education, will benefit participants by reducing the likelihood of becoming overweight or obese.

\section{Estimation strategy}

The two outcomes of interest used to measure the impact of Head Start participation are overweight and obesity. Let $\mathrm{Y}$ denote these outcomes, where $\mathrm{Y}=1$ if the individual is overweight or obese, depending on the outcome, and $\mathrm{Y}=0$ otherwise. Let $\mathrm{D}$ be an indicator variable for whether an individual has participated in Head Start. Let $Y_{1}$ and $Y_{0}$ denote the potential outcomes for an individual if they had participated in Head Start (i.e., if $\mathrm{D}=1$ ) and if they had not (i.e., if $\mathrm{D}=0$ ).

The focus of this paper is to estimate the average effect of Head Start participation on overweight and obesity for individuals who participated in Head Start (i.e., the average treatment effect on the treated). ${ }^{2}$ This impact of Head Start is defined as $E\left(Y_{1}-Y_{0} \mid D=1\right)$. This expectation is equal to $\operatorname{Pr}\left(Y_{1}=1 \mid \mathrm{D}=1\right)-\operatorname{Pr}\left(\mathrm{Y}_{0}=1 \mid \mathrm{D}=1\right)$, which is the difference between the probability that an individual who attended Head Start is overweight or obese and the

\footnotetext{
${ }^{2}$ For a general discussion of treatment effect estimation, see Heckman, LaLonde, and Smith (1999).
} 
probability that a Head Start participant would have been overweight or obese had they not attended Head Start. The identification problem that arises in estimating this treatment effect is that because $\mathrm{Y}_{1}$ and $\mathrm{Y}_{0}$ cannot exist for the same individual (i.e., an individual either attended Head Start or did not), the counterfactual outcome $\operatorname{Pr}\left(\mathrm{Y}_{0}=1 \mid \mathrm{D}=1\right)$ is unobservable. Instead, $\mathrm{Y}$ $=\mathrm{Y}_{1} \times \mathrm{D}+\mathrm{Y}_{0} \times(1-\mathrm{D})$ is observed for each individual.

The probabilities that are easily computable with cross-sectional data are $\operatorname{Pr}\left(\mathrm{Y}_{1}=1 \mid \mathrm{D}=\right.$ 1) and $\operatorname{Pr}\left(Y_{0}=1 \mid \mathrm{D}=0\right)$. Under the assumption that $\operatorname{Pr}\left(\mathrm{Y}_{0}=1 \mid \mathrm{D}=1\right)=\operatorname{Pr}\left(\mathrm{Y}_{0}=1 \mid \mathrm{D}=0\right)$, then

$$
\mathrm{E}\left(\mathrm{Y}_{1}-\mathrm{Y}_{0} \mid \mathrm{D}=1\right)=\operatorname{Pr}\left(\mathrm{Y}_{1}=1 \mid \mathrm{D}=1\right)-\operatorname{Pr}\left(\mathrm{Y}_{0}=1 \mid \mathrm{D}=0\right),
$$

and the impact of Head Start participation could be estimated by comparing the difference in the sample means of overweight and obesity rates for Head Start participants and non-Head Start participants in any nationally representative survey. However, this assumption implies that the outcomes of individuals who did not attend Head Start would be the same as Head Start participants under the hypothesized counterfactual state that these individuals had not attended Head Start (i.e., $Y_{0} \perp$ D). This assumption is not likely to be correct because of both observable selection and unobservable selection of individuals into the program.

Observable characteristics associated with selection into Head Start are likely to be associated with childhood obesity. As described in the previous section, poverty status and disability status are the key eligibility criteria for Head Start participation. Thus, if either poverty status or disability status is correlated with childhood obesity, then the observable determinants of Head Start participation also influence childhood obesity, and $\mathrm{Y}_{0}$ is not independent of D. Because income constraints influence which foods are available for consumption and cheaper foods are often high in fats and caloric content, poverty status may be 
related to childhood obesity. Hofferth and Curtin (2005) show that children in families below the poverty line are more likely to be obese than children in families with incomes twice the poverty line. To incorporate observable selection, the impact of Head Start participation becomes $\mathrm{E}\left(\mathrm{Y}_{1}-\mathrm{Y}_{0} \mid \mathrm{X}, \mathrm{D}=1\right)$, where $\mathrm{X}$ represents observed family and individual characteristics. Under the assumption that $\operatorname{Pr}\left(\mathrm{Y}_{0}=1 \mid \mathrm{X}, \mathrm{D}=1\right)=\operatorname{Pr}\left(\mathrm{Y}_{0}=1 \mid \mathrm{X}, \mathrm{D}=0\right)$, then

$$
\mathrm{E}\left(\mathrm{Y}_{1}-\mathrm{Y}_{0} \mid \mathrm{X}, \mathrm{D}=1\right)=\operatorname{Pr}\left(\mathrm{Y}_{1}=1 \mid \mathrm{X}, \mathrm{D}=1\right)-\operatorname{Pr}\left(\mathrm{Y}_{0}=1 \mid \mathrm{X}, \mathrm{D}=0\right) .
$$

This treatment effect could be estimated with a probit model. Under the specification $\operatorname{Pr}(\mathrm{Y}=1)$ $=\operatorname{Pr}(\mathrm{X} \beta+\mathrm{D} \alpha+\varepsilon>0)=\Phi(\mathrm{X} \beta+\mathrm{D} \alpha)$, where $\beta$ and $\alpha$ represent the coefficients to be estimated, $\varepsilon$ is a standard normally distributed random error term, and $\Phi($.$) is the standard normal cdf, the$ impact of Head Start participation is $\mathrm{E}\left(\mathrm{Y}_{1}-\mathrm{Y}_{0} \mid \mathrm{X}, \mathrm{D}=1\right)=\Phi(\mathrm{X} \beta+\mathrm{D} \alpha)-\Phi(\mathrm{X} \beta)^{3}$

The assumption that $\operatorname{Pr}\left(\mathrm{Y}_{0}=1 \mid \mathrm{X}, \mathrm{D}=1\right)=\operatorname{Pr}\left(\mathrm{Y}_{0}=1 \mid \mathrm{X}, \mathrm{D}=0\right)$ states that, after adjusting for observed individual and family background characteristics, the probability that a non-Head Start participant is overweight or obese would be the same regardless of whether the child attended Head Start (i.e., $\mathrm{Y}_{0} \perp \mathrm{D} \mid \mathrm{X}$ ). This assumption is unlikely to hold if unobserved behaviors that are related to childhood obesity influence whether an individual attends Head Start. Because parents choose to send their child to Head Start, it is possible that they also make other investments that could influence their child's later health and weight outcomes. For example, in 2004, 27 percent of Head Start staff members were parents of current or former Head Start participants, and over 880,000 parents volunteered with Head Start (Head Start Bureau, 2005). These parents have made a commitment to their children that could lead to a bias

\footnotetext{
${ }^{3}$ Alternatively, the impact of Head Start participation could be estimated using propensity score-matching. In the method of matching, individuals who are similar in observable characteristics from both treatment and control groups are paired together. The treatment effect is then the difference in outcomes for these matched individuals. Propensity score-matching reduces the dimensionality of the characteristics need to match individuals by using the probability of receiving treatment conditional on observable characteristics, which is an individual's propensity score. For an application of this technique, see Dehejia and Wahba (2002).
} 
towards finding positive impacts from Head Start participation estimated through a probit model. ${ }^{4}$ However, this does not seem to be likely. Head Start children were not more likely, compared to non-Head Start children, to be breastfed as infants, which is linked to a variety of health benefits including lower obesity rates (Dietz, 2001), or be properly immunized prior to Head Start attendance - both of which are behaviors that would signal parental decisions to invest in the health of their child. ${ }^{5}$

Because children selected by program administrators are the most disadvantaged of the Head Start-eligible applicants in the program's service area, it is likely that these individuals are disadvantaged across a variety of dimensions, not simply the observable characteristics that determine Head Start eligibility. If Head Start participants are more disadvantaged than their peers in ways unobservable to an econometrician and if these sources of disadvantage are related to future health and weight outcomes, then estimated average treatment effects that ignore these unobserved characteristics will be biased against finding a beneficial impact of Head Start participation. Unobserved determinants of Head Start participation include the severity of a disability, the family environment experienced by a child in a family classified as high risk, and any other characteristic that is associated with Head Start children and families, but not associated with other families with similar incomes.

Disability status is correlated with overweight and obesity (Rimmer and Wang, 2005). Individuals with intellectual disabilities are more likely to be obese, and individuals with more severe disabilities are even more likely to be obese (Emerson, 2005). Thus, for individuals with

\footnotetext{
${ }^{4}$ Estimates based on propensity score-matching are also likely to be biased under this scenario and other situations in which unobserved behaviors that are related to childhood obesity influence whether an individual attends Head Start.

${ }^{5}$ The statements in this sentence are based on regression estimates (not shown) from probit models with indicator variables for having been breastfed and having been properly immunized as the outcome variables. The control variables used were the same as those displayed in Table 2.
} 
severe disabilities, the impact of Head Start participation estimated from a probit model that controls for only the disability status of an individual is likely to be downward biased.

A child's family environment is an important determinant of future overweight and obesity. Exposure to childhood emotional, physical, or sexual abuse and household dysfunction in childhood are associated with adverse health behaviors later in life, including severe obesity (Felitti et al, 1998). Women raised in families characterized by family tension at mealtimes or frequent parental arguments, who received little parental affection, who had limited contacts with parents, or who cared for an ill parent are more likely than other women to develop a binge eating disorder (Striegel-Moore et al, 2005), and a binge eating disorder is associated with child and adult obesity (Lamerz et al, 2005). Because individuals in an abusive family environment are more likely to be accepted in to Head Start and these individuals are also more likely to be overweight or obese later in life, estimates based on models that do not account for these relationships are likely to be biased.

Additionally, individuals who are disadvantaged across observed characteristics are also likely to be disadvantaged in a variety of unobserved characteristics (e.g. Altonji, Elder, and Taber, 2005). Some important characteristics not observed are parents' nutritional behaviors and parents’ nutritional knowledge. Parents’ nutritional behaviors influence childhood obesity because the amount of food children eat is determined by the amount of food they are served, and children do not adjust their consumption in response to the energy density of the meal (Mrdjenovic and Levitsky, 2005). Parents' nutritional knowledge is an important determinant of children's diets, especially at younger ages (Variyam et al, 2005). Head Start parents' nutritional knowledge and behaviors may differ from other parents in ways that are not captured in parents' body mass index. Therefore, estimates of the impact of Head Start participation that fail to 
completely account for the disadvantaged family environment of the program's participants are likely to be biased downwards.

An instrumental variables approach that accounts for the binary nature of the outcome and treatment variables is implemented to allow for the possibility that unobserved selection influences the estimated impact of Head Start participation. The probability of Head Start attendance is specified as:

$$
\operatorname{Pr}(\mathrm{D}=1)=\operatorname{Pr}(\mathrm{Z} \delta+v>0)
$$

and the probability of being overweight or obese is specified as:

$$
\operatorname{Pr}(\mathrm{Y}=1)=\operatorname{Pr}(\mathrm{X} \beta+\mathrm{D} \alpha+\varepsilon>0)
$$

where $\mathrm{Z}$ and $\mathrm{X}$ represent observable characteristics that are independent of $(\mathrm{v}, \varepsilon)$ and $\mathrm{Z}$ contains at least one variable that is not in $\mathrm{X} ; \delta, \beta$, and $\alpha$ are parameters to be estimated; and $v$ and $\varepsilon$ are random error terms. The assumption that $v$ and $\varepsilon$ are distributed bivariate normal with $\mathrm{E}(\mathrm{v})=0$, $\mathrm{E}(\varepsilon)=0, \operatorname{Var}(\mathrm{v})=1, \operatorname{Var}(\varepsilon)=1$, and $\operatorname{Cov}(\mathrm{v}, \varepsilon)=\rho$ allows for the possibility that the unobserved determinants of Head Start participation are correlated with the unobserved determinants of overweight and obesity. Under this estimation strategy, which accounts for observable and unobservable selection, the impact of Head Start participation is $E\left(Y_{1}-Y_{0} \mid X, D=1\right)=\Phi(X \beta+$ $\mathrm{D} \alpha)-\Phi(\mathrm{X} \beta)$

An appropriate choice for an instrument is a variable that is related to Head Start attendance, but is not directly related to overweight or obesity, which ensures that the variable is contained in $\mathrm{Z}$ but not $\mathrm{X} .{ }^{6}$ Program availability will influence the probability that a child attends

\footnotetext{
${ }^{6}$ A logical starting point in finding an instrument would be the eligibility criteria for Head Start; however, eligibility is determined by poverty status (constructed from family income and family size) and disability status. These variables are likely to influence the outcome variables directly and should be included in X. An additional approach to identify the treatment effect of Head Start participation is to use the discontinuity in program funding that resulted because the Office of Economic Opportunity provided grant writing assistance to the 300 poorest counties, but not
} 
Head Start, but is not likely to impact the probability that a child is overweight or obese independent of the association with Head Start attendance. Head Start is not a fully funded program, in the sense that some eligible children who apply for admission are not admitted due to funding constraints. Only about 55 percent of eligible children are able to attend the program. ${ }^{7}$ Prior to the selection decisions of the program administrators, the probability that a child who is eligible for Head Start will attend is based on the number of available slots in the local program divided by the number of children in the service region who are eligible.

Therefore, the instrument for Head Start participation is the relative availability of Head Start: the enrollment divided by the number of eligible children in a Head Start service area.

The number of funded slots available in a program is determined by the Department of Health and Human Services based on the historical evolution of funding to the local program and changes in the federal appropriations to Head Start. The number of funded positions for each grantee does not always fluctuate annually, but was likely to increase throughout the latter part of the twentieth century when Head Start enrollment changed from 448,464 children in 1988 to 905, 235 children in 2001 due to an over 400 percent increase in funding (Head Start Bureau, 2005). Increases in appropriations are first used to increase the quality of existing programs, and then remaining funds are distributed based on the number of eligible children not served by Head Start, which is commonly driven by changes in the population. ${ }^{8}$ Currie and Neidell

other counties, prior to the initial appropriation of Head Start funds (e.g., Ludwig and Miller, 2005). While the discontinuity in funding persisted over time, it did not persist throughout the 1990s (Ludwig and Miller, 2005), and, thus, would not be appropriate for this analysis.

7 This estimate is based on the author's calculations from data available from the Head Start Bureau and the Census Bureau. In 2004, 905,851 children attended Head Start and 4,116,000 children under age 5 lived in families below poverty. Assuming that 2/5ths of the children under age 5 are ages 3 or 4 and that income is the only determinant of eligibility, then 1,646,400 children are eligible for Head Start. Thus, about 55 percent of income-eligible children attend Head Start.

${ }^{8}$ By 1988, the Head Start program had sufficiently expanded throughout the country that almost al counties offered Head Start services. If better quality program directors are able to obtain additional funds, and better quality program directors administer higher quality programs, then funding and the number of funded slots could be related 
(forthcoming) report that expenditure levels of Head Start programs has no detectable effect on the observable characteristics of children selected in the program or who chose to enroll in the program. Therefore, variation in the number of Head Start openings available to a child in a given year is determined by federal legislation and the extent to which the local community was underserved by Head Start - factors that are unlikely to be related to the unobserved determinants of childhood overweight and obesity. The number of children in the community who are eligible for Head Start services is based on the local variation in the size of the population of children ages 3 through 5 , and business cycle fluctuations that influence the number of families in poverty status, factors that are likely to be exogenous for a Head Start participant. $^{9}$

to child outcomes and childhood obesity. However, Currie and Neidell (forthcoming) find no evidence that program directors' education, experience, or salary is positively related to children's educational outcomes. If additional funds are appropriated to local programs based on the quality of the program and the quality of the program influences a family's decision to enroll their child and the outcomes from the program, then the number of funded positions in a local Head Start is not exogenous. In this case, community dummy variables could be included to control for the unobservable quality of the program. Then, the instrument identifies Head Start participation based on variation in the number of funded slots within the community. Including community fixed effects is explored in a linear IV model, but not in the bivariate probit model. Models with community fixed effects show a larger impact of Head Start participation than the linear IV results described in the appendix tables. Additional specifications include adding region dummy variables and state dummy variables to the bivariate probit models that account for endogenous selection; estimates from these specifications are similar to those presented in Tables 3 and 4.

${ }^{9}$ Ruhm (2000, 2005) finds that temporary economic downturns are related to better health behaviors for adults, largely due to declining work hours. While macroeconomic conditions are not likely to directly influence children's health behaviors, temporary economic downturns might influence childhood obesity if parents reduce their work hours and spend more time preparing healthier meals, ignoring the influence of income on food purchases and obesity. Economic recessions would increase the number of children eligible for Head Start as the number of children in families below the poverty line rises, which would decrease the value of the instrument. Thus it could be the case that the relative availability of Head Start influences the probability that a child attends Head Start and has an independent effect on childhood obesity. Based on the results described later, a decrease in the relative availability of Head Start would decrease the probability that a child attends Head Start, and would increase the probability that a child is obese. On the other hand, a decrease in the relative availability of Head Start that is driven by economic downturns could have a direct decrease in the probability that a child is obese because of the influence of the macroeconomy on work hours and parental behavior. Thus, business cycle fluctuations would have a larger impact on childhood obesity if the business cycle only influenced the size of the population eligible for Head Start. So if it is the case that temporary economic downturns are related to the relative availability of Head Start and childhood obesity, then the estimated results understate the true impact of Head Start participation. It is important to note, however, that, as of 1995, only 28 percent of Head Start parents were employed full time and 17 percent were employed part-time (Blau and Currie, forthcoming). 


\section{Data}

The impact of Head Start participation on childhood overweight and obesity is evaluated using data from the Panel Study of Income Dynamics (PSID) and its Child Development Supplement (CDS). The PSID is a longitudinal study of U.S. households and individuals that began in 1968 with a national sample of approximately 4,800 households. Members of these households, their offspring, and current co-residents have been interviewed on an annual or biennial basis since the inception of the PSID. In 1997, the CDS collected additional information about PSID parents and their children ages 0-12 years. A total of 2,394 families and 3,563 children were interviewed. In 2002, 2,021 families and 2,907 children ages 5 to 19 years were re-interviewed.

A variety of health, education, and childcare variables are collected in the CDS, but most importantly for this research, Head Start participation was identified and height and weight were measured by the interviewer in 2002. ${ }^{10}$ Objective measurements of height and weight are important because self-reported measures of weight are subject to reporting error (Cawley, 2000). The outcome variables for this analysis - a binary variable equal to one if the child is overweight or obese and a binary variable equal to one if the child is obese - are determined using the international standards for childhood overweight and obesity established by Cole et al (2000). ${ }^{11}$ These age- and gender-specific cutoffs for children at least 2 years old are based on

\footnotetext{
${ }^{10}$ Height and weight were measured without shoes on and with empty pockets. If the child refused to be measured, then height and weight were self-reported by either the child or the parent. In the analysis sample of 2,301 children, the height and weight of 22 children were self-reported instead of being measured by the interviewer. Removing these 22 children from the sample does not qualitatively change the results displayed in Tables 3 and 4 . Black children who attended Head Start were 33.2 percentage points (s.e. $=0.162$ ) and 32.9 percentage points (s.e. $=0.161$ ) less likely to be overweight or obese compared to other black children.

${ }^{11}$ Alternative measures of child overweight and obesity developed by the Centers for Disease Control and Prevention are a body mass index above the $85^{\text {th }}$ percentile and the $95^{\text {th }}$ percentile, respectively. These measures are often referred to in the medical literature as "at risk of overweight" and "overweight." Using these measures
} 
body mass index, a measure which is correlated with body fat and is recommended by the National Heart, Lung, and Blood Institute for use in clinical practice and epidemiological studies (National Heart, Lung, and Blood Institute, 1998).

Individual characteristics included in both $\mathrm{X}$ and $\mathrm{Z}$ are race (white, black, Hispanic, and other race), birth weight and birth weight squared, a binary variable indicating that the individual is the oldest child, and a binary variable equal to one if the individual is disabled. Measures of parents' marital status (single, married, divorced, and widowed) and residence (suburban, urban, and rural) are also included. Mothers' and fathers' body mass index and their squared terms, measured in 1986 prior to children being age-eligible for Head Start attendance, are included. Body mass index measures prior to Head Start attendance are important because current measures of parental BMI could be influenced by the child's Head Start participation. ${ }^{12}$ Family income and family size are averaged over the years when the child was ages 3 through 5 . Additionally, an indicator variable equal to one if the father was not present during the ages 3 through 5 is included.

The relative availability of Head Start when the child was 3 and 4 years old - the percent of eligible children in the community who attended Head Start - is calculated based on enrollment figures for each Head Start program in the Head Start Program Information Reports and the number of children in poverty in the U.S. Census Bureau's Small Area Income and

\footnotetext{
decreases the prevalence of overweight but increases the prevalence of obesity in this sample. For the alternative measures of child overweight and obesity, black children who attended Head Start were 30.1 percentage points (s.e. $=0.196)$ and 33.1 percentage points (s.e. $=0.140$ ) less likely to be overweight or obese compared to other black children. The point estimate for overweight is measured with less precision using this alternative definition of overweight (and is smaller); however, the estimate for all children pooled together is very similar for both measures - Head Start participants are 25.6 percentage points (s.e.=0.073) less likely to be overweight compared to children who did not attend Head Start.

${ }^{12}$ If the nutritional education provided to parents influences their nutritional behavior, then current measures of body mass index are an outcome of the child's Head Start participation, as opposed to an exogenous determinant of the child's probability of being overweight or obese.
} 
Poverty Estimates. This measure is then linked to the PSID and CDS data through the county identifying codes in the restricted-access PSID geocode file. ${ }^{13}$

For an individual to be included in the analysis sample, the child must have height and weight information in the 2002 CDS, information about Head Start attendance, have been a member of a responding family to the PSID at age 3 or 4, and report the county of residence at age 3 or 4 . These sample restrictions yield 2,301 children. Missing data for the other variables are imputed using linear regression based on the control variables with non-missing data. ${ }^{14}$

Table 1 describes the characteristics of the sample and displays the differences between Head Start participants and non-Head Start participants. The sample means, with standard errors in brackets, are weighted by the 2002 CDS survey weight to be nationally representative of children ages 5 through 19 . These data show that Head Start participants are more likely to be overweight and obese than non-Head Start participants. If the assumption $\operatorname{Pr}\left(\mathrm{Y}_{0}=1 \mid \mathrm{D}=1\right)=$ $\operatorname{Pr}\left(Y_{0}=1 \mid \mathrm{D}=0\right)$ was true, then this comparison between sample means would suggest that Head Start worsens the health of participants. However, it is also shown in Table 1 that Head Start participants are less likely to be the oldest child, more likely to have a disability, and less likely to have married parents. Additionally, Head Start participants were raised in larger families with lower incomes, with less educated parents, with mothers with a higher body mass index, and with fathers less likely to be present. These differences in individual and family characteristics highlight the need to control for observable characteristics to determine the impact of Head Start participation.

\footnotetext{
${ }^{13}$ Further information about the construction of each variable is available in the data appendix.

${ }^{14}$ Five missing observations were imputed for family income, 19 for the oldest sibling dummy, 3 for urbanicity, 109 for mothers' education, 598 for fathers' education, 414 for mothers' body mass index, 809 for fathers' body mass index, 2 for disability, and 67 for birth weight. The high numbers of missing observations for the fathers' variables are present because 31 percent of the sample did not have a father as part of the family during the preschool years. Additionally, five missing observations were imputed for race; these five individuals were not included in the racespecific samples analyzed in the next section.
} 
Head Start participants are also more likely to be black. Because the prevalence of overweight and obesity differs by race and the impact of Head Start participation differs by race for educational and social outcomes (Garces, Thomas, and Currie, 2002), the impact of Head Start participation on overweight and obesity is also examined separately by race. The descriptive statistics of blacks and whites are included in Table 1. Blacks are more likely than whites to be overweight and obese, and are disadvantaged, in comparison to whites, based on family background characteristics.

\section{Results}

Table 2 displays probit estimates of the relationship between Head Start participation and childhood overweight and obesity that do not include an instrument for Head Start participation. ${ }^{15}$ The reported coefficients are marginal effects. These results demonstrate that under the assumption $\operatorname{Pr}\left(\mathrm{Y}_{0}=1 \mid \mathrm{X}, \mathrm{D}=1\right)=\operatorname{Pr}\left(\mathrm{Y}_{0}=1 \mid \mathrm{X}, \mathrm{D}=0\right)$, Head Start participation has no statistically significant impact on the probability that an individual is overweight or obese.

Table 3 displays the bivariate probit estimates that identify the impact of Head Start participation by using the relative availability of Head Start to instrument for participation in the program. ${ }^{16}$ The average treatment effect on the treated is a reduction of 24.9 percentage points (s.e. $=0.075$ ) in the probability of being overweight for all individuals. The estimate of $\rho$ is

\footnotetext{
${ }^{15}$ Estimation of the average treatment effect on the treated using propensity score-matching yields qualitatively similar results to the average treatment effect on the treated based on the probit estimates reported in Table 2.

${ }^{16}$ These estimates do not include age and gender because both age and gender are incorporated into the definitions of childhood overweight and obesity. When age and gender are included in the models, neither variable has a significant impact on overweight or obesity. However, older children are significantly less likely to have attended Head Start than younger children. This result occurs because of the large increases in Head Start funding that occurred throughout the 1990s, which lead to greater numbers of children enrolling in the program. The increases in enrollment are an exogenous source of variation that is captured by the instrument and is unrelated to childhood overweight and obesity. However, it is possible that the time trend in Head Start enrollment that underlies the age variable is related to time trends in childhood overweight and obesity. Including age and gender in the models, Head Start participants are 22.2 percentage points (s.e. $=0.077$ ) less likely to be overweight. Black Head Start participants are 26.2 percentage points (s.e. $=0.176$ ) and 32.9 percentage points (s.e. $=0.161$ ) less likely to be overweight or obese compared to other black children.
} 
positive and statistically significant, which means that the unobserved characteristics that influence Head Start participation are positively correlated with the unobserved determinants of overweight. This is consistent with the idea that the children who are selected into the program are the most disadvantaged of the eligible children in both observed and unobserved characteristics.

After dividing the sample by race, it becomes evident that the previous result holds strongly among black children, but is weaker among whites. Black Head Start participants are 33.4 percentage points (s.e. $=0.157$ ) less likely to be overweight during the ages of 5 through 19 than black children who did not attend Head Start, holding other characteristics fixed. The estimate of the correlation coefficient is 0.595 with a standard error of 0.288 . The corresponding heteroskedasticity-robust Wald statistic used to test the null hypothesis that the population correlation parameter is zero is 2.366; based on the chi-square distribution with one degree of freedom, the null hypothesis cannot be rejected for a level of significance less than 0.124 . While this is not statistically significant at conventional levels, the size of the correlation estimate suggests that there is a relationship between $v$ and $\varepsilon$ and the bivariate probit model should not be rejected in favor of the probit estimates.

Table 4 displays the estimates of the bivariate probit model for the relationship between Head Start participation and childhood obesity that includes the instrument. ${ }^{17}$ The average

\footnotetext{
${ }^{17}$ One concern that arises because of the Head Start eligibility criteria is that, as evidenced in the descriptive statistics in Table 1, the Head Start (treatment) group is sufficiently different from the non-Head Start (control) group that regression methods are not able to adequately adjust across these two groups to elicit comparisons between a child who attended Head Start and an otherwise similar child who did not attend. To address this concern, the propensity score that an individual would attend Head Start is estimated and individuals not included in the common support are removed from the analysis sample. This insures that the Head Start and non-Head Start samples more closely overlap. The region of common support based on the propensity score is [0.0015, 0.8735$]$. This removed 310 children with propensity scores below the region of common support and one child with a propensity score above the region of common support. Estimates of the impact of Head Start participation using bivariate probit models for this restricted sample differed little from the estimates reported in Tables 3 and 4 . Black children who attended Head Start were 33.9 percentage points (s.e. $=0.167)$ and 33.8 percentage points (s.e. $=0.154$ )
} 
treatment effect on the treated for all individuals is not statistically different from zero, but after examining this relationship separately for black and white children, a different picture of the impact of Head Start participation emerges. Black children who participated in Head Start are 33.2 percentage points (s.e. $=0.158$ ) less likely to be obese than other black children. Once again, the correlation coefficient for the error terms is large (0.757), although not statistically significant for significance levels less than 0.161 .

While these results are significant, their credibility rests on the validity of the instrument. This requires that the relative availability of Head Start is correlated with Head Start participation but not otherwise correlated with the unobserved determinants of childhood overweight and obesity. No statistical tests of these assumptions have been designed specifically for the bivariate probit model; therefore, these assumptions are tested in a linear IV model. ${ }^{18}$ Within this framework, the F statistic on the excluded instrument - based on a linear regression of Head Start participation on Z - is 18.32 for all children, 11.46 for black children, and 8.62 for white children. This suggests that the percent of eligible children in the community who attend Head Start is strongly correlated with whether a child participates in Head Start. Thus, there is not a weak instrument problem (Staiger and Stock, 1997). A test of overidentifying restrictions, which jointly tests the hypotheses of correct model specification and that the excluded instruments are not correlated with the error term, is not available, however, for the case where there is one endogenous variable and one excluded instrument.

A concern with the bivariate probit model is that the linearity and normality assumptions or the exclusion restriction is driving the identification of the estimated treatment effect of Head

less likely to be overweight or obese compared to other black children. Restricting the sample to individuals who were eligible for Head Start reduces the sample of blacks to 628 individuals. The point estimates for this sample are larger in absolute terms ( -0.495 for overweight and -0.434 for obesity), but only the estimate for overweight is statistically significant.

${ }^{18}$ Linear IV results are available in Appendix Tables 1 and 2. 
Start participation (Altonji, Elder, and Taber, 2005b). If the linearity and normality assumptions of the model are the primary source of identification, then the use of a weak instrument can lead to seemingly precise estimates of the treatment effect. Following Altonji, Elder, and Taber (2005b), I replace the relative availability of Head Start with a weak instrument to see how the estimated impact of Head Start participation changes. If the estimates do not change significantly, then identification results from the functional form assumptions, not from the instrument. The other instrument used is the log of the average cost of childcare in the state. The log of the average cost of childcare in the state is likely to be related to Head Start participation because Head Start may be viewed by some parents as a substitute for childcare and this cost is unlikely to be related in other ways to childhood overweight and obesity. This instrument is not included in the main specifications because including it is a weak predictor of Head Start participation. For the estimates of childhood obesity for the black sample, with the log of average child care costs in the state as the only instrument, the coefficient for child care costs is -0.364 (s.e. $=0.605$ ) and the coefficient for Head Start is -0.752 (s.e. $=2.315$ ), which leads to an ATT of -0.207 with a standard error of 0.666 . The coefficient is smaller and is not estimated precisely, suggesting that the primary source of identification in the bivariate probit model is the instrument (the relative availability of Head Start) and not the functional form assumptions of the model.

The results describing a significant impact on childhood overweight and obesity for black Head Start participants, but not whites, raise questions about why these results differ by race. Previous research that has evaluated the impact of Head Start found that the benefits, in terms of cognitive achievement, persist for whites, but not for blacks. Interestingly, splitting the sample of black children into two groups - ages 5 to 12 and ages 12 to 19 - and estimating a bivariate 
probit model for each age group reveals that results displayed in Tables 3 and 4 do not persist. ${ }^{19}$ Younger black children who attended Head Start were 46.8 percentage points (s.e.=0.069) and 44.4 percentage points (s.e. $=0.030$ ) less likely to be overweight or obese compared to other black children ages 5 to 12 . However, there was no statistically significant effect of Head Start participation on the probability of overweight or obesity for older black children. ${ }^{20}$ These results for overweight and obesity suggest that, similarly to achievement scores, Head Start participation leads to a substantial initial benefit that does not persist.

One possible explanation for the results that Head Start participation reduces the probability of becoming overweight or obese for blacks and that this health benefit does not persist into an individual's teenage years is that overweight and obesity are related to cognitive achievement. For blacks, the low quality of schools attended after Head Start causes the achievement benefits from Head Start participation to be short-lived (Currie and Thomas, 2000). It is well established that education and health are related, and Chou, Grossman, and Saffer (2002) demonstrate that schooling and obesity are related. It is less clear, however, whether childhood achievement scores are related to obesity. Perhaps, Head Start increases the nutritional education of participants, which positively influences nutritional behavior, but that the low quality of subsequent schooling erases the gains achieved during Head Start. ${ }^{21}$

\footnotetext{
${ }^{19}$ For this sample, there are 484 black children older than 5 years old and less than 12 years old and 489 black children at least 12 years old.

${ }^{20}$ The point estimate of the average treatment effect on the treated for overweight was -0.070 with a standard error of 0.199 ; the point estimate for obesity was 0.041 with a standard error of 0.260 .

${ }^{21}$ Unfortunately, the nutritional knowledge of children is not available in the dataset used for this analysis. Nutritional knowledge is available for parents only in 1999. Descriptive analysis suggests that, for blacks, the nutritional knowledge of parents of Head Start child is not statistically different from that of other parents. The similarity in nutritional knowledge may result because the nutritional education programs in Head Start increased the knowledge of Head Start parents to be comparable to other parents. If this were the case, then the increased nutritional knowledge did not strongly influence parents' nutritional behavior. Analysis of the BMI of parents demonstrates no statistical difference in the change in BMI after children attend Head Start (1999) versus prior to children attending Head Start (in 1986) for black Head Start parents compared to other black parents.
} 
An additional explanation that is similar to the one offered above is that the low quality schools that blacks attend after Head Start offer food services that are lacking in nutritional value. Anderson and Butcher (2005) document that schools under financial pressure are more likely to make junk foods available through vending machines or school stores, are more likely to grant a soft drink manufacturer exclusive rights to supply their soft drink to students, and are more likely to allow soda or snack food advertising. The authors demonstrate that these food policies, particularly the availability of junk food, lead to an increase in children's body mass index. Thus, if black Head Start participants attend primary or secondary schools under financial pressure, then the food policies and the quality of the school food of the subsequent schools could counteract the Head Start benefits. However, these explanations that emphasize the influence of later schooling do not clarify why the reduced rates of childhood overweight and obesity do not occur for whites. ${ }^{22}$

An alternative explanation for the racial differences in the benefits of Head Start participation and the reduction in benefits over time is that Head Start provides nutritious foods, which may compensate for the lack of access to healthy foods in poor, black neighborhoods. ${ }^{23}$ This is a plausible explanation if access to nutritious foods differs between low-income black households and low-income white households. The increase in nutritional access would provide

\footnotetext{
${ }^{22}$ An alternative explanation for the result that the overweight and obesity benefits fade with age is that, because the age effect cannot be distinguished from the cohort effect, the quality of Head Start programs has recently increased. Thus, younger children would show a larger benefit from the program.

${ }^{23}$ Although the national figures for Head Start suggest that many races and ethnicities are present in the program, at the local level, there is a high degree of racial segregation, which reflects the racial composition of the local communities. For example, when black participants are the most represented racial group in a program, 73 percent of the participants are black. This is true for whites as well (source: authors calculations based on the 2002 Head Start Program Information Reports). When blacks are the dominant racial group, only 11 percent of the participants are white. When whites are the dominant racial group, only 9 percent of the participants are black. Thus, black and white Head Start participants are likely to attend different programs.
} 
short-term benefits to children and these benefits would begin to fade away after this access ends. $^{24}$

Among poor neighborhoods, distance to supermarkets is much greater for predominantly black neighborhoods than predominantly white neighborhoods (Zenk et al, 2005) and access to supermarkets positively influences dietary patterns (Morland, Wing, and Diez Roux, 2002). Residing in a census tract with one supermarket is associated with an increased intake of fruits and vegetables for blacks, compared to a neighborhood without supermarkets, and a second supermarket is associated with a further increase in the consumption of fruits and vegetables (Morland, Wing, and Diez Roux, 2002). On the other hand, residing in a neighborhood with a small grocery store is not associated with higher levels of fruit and vegetable consumption for blacks (Morland, Wing, and Diez Roux, 2002). Supermarkets provide better availability and selection of nutritious foods and higher quality foods at a lower cost than smaller food providers (Zenk et al, 2005). Among the most impoverished neighborhoods, the nearest supermarket to predominantly black neighborhoods is slightly over one mile farther away than the nearest supermarket to predominantly white neighborhoods (Zenk et al, 2005). Within a 3-mile radius of the most impoverished neighborhoods, there were approximately two and a half fewer supermarkets for predominantly black neighborhoods than predominantly white neighborhoods (Zenk et al, 2005). Clearly, access to nutritious foods is greater for poor white children than poor

\footnotetext{
${ }^{24}$ If the provision of nutritious foods is the driving force behind these results, then this explanation raises additional questions about why other programs that provide food to low-income children do not have the same benefits. For example, the overweight and obesity benefits for black children should persist if other governmental programs that target older children also provide access to nutritious foods. However, the relationship between poverty and poor nutrition is stronger for preschool children than older children (Bhattacharya, Currie, and Haider, 2003). Regarding the nutritional benefits of other food provision programs, Food Stamp Program participants increase their consumption of meats, sugars, and fats, as opposed to fruits, vegetables, grains, or dairy products (Wilde, McNamara, and Ranney, 2000). Participation in the National School Lunch Program and the School Breakfast Program leads to the consumption of a higher percentage of calories from fat and saturated fat (Gordon, Devaney, and Burghardt, 1995). Bhattacharya, Currie, and Haider (2004) find that the School Breakfast Program increases the quality of dietary intake for high income children, but not children in families below the poverty line. Participation in these three programs is not shown to lead to a decrease or an increase in childhood overweight or obesity (Hofferth and Curtin, 2005).
} 
black children. Thus, for black Head Start participants, access to healthy foods would be limited without the availability of Head Start, while the same would not be true for white Head Start participants. This explanation suggests that the provision of nutritious foods provides short-term benefits to Head Start participants that diminish with time.

\section{Conclusion}

This paper estimates the impact of Head Start participation on childhood overweight and obesity for individuals ages 5 through 19. Because of the nutrition services and nutrition education provided to parents and children, Head Start participation is expected to influence participants' nutritional behavior and affect childhood overweight and obesity. Plausibly exogenous variation in the relative availability of Head Start in the local community is used to identify the average treatment effect on Head Start participants. The results demonstrate that Head Start significantly reduced the probability that a black participant would become overweight or obese in later childhood. This finding is significant because many of the educational benefits of Head Start participation that have been previously estimated demonstrate a positive impact of the program for whites, but not blacks. This suggests that Head Start participation can influence outcomes for all of the participants, not just whites. Additionally, these results suggest that the influence on overweight and obesity results from the nutritional services in the program, not because Head Start improved educational outcomes that had secondary health benefits. It is likely that the reduction in childhood overweight and obesity from Head Start participation results from the provision of nutritious foods, in addition to the parent and child nutritional education. Further research, however, is needed to more completely discern the importance of the different pathways through which Head Start's services can reduce 
childhood obesity. Until then, it is difficult to gauge the role of Head Start as a policy in reducing the prevalence of childhood obesity. Demonstrating that Head Start participation can influence a wider set of outcomes than previously considered, however, is an important contribution to the policy discussion of the efficacy of investments in early childhood. 


\section{References}

Altonji, Joseph, Todd Elder, and Christopher Taber (2005a) "Selection on Observed and Unobserved Variables: Assessing the Effectiveness of Catholic Schools,” Journal of Political Economy, 113 (1), 151-184.

Altonji, Joseph, Todd Elder, and Christopher Taber (2005b) “An Evaluation of Instrumental Variable Strategies for Estimating the Effects of Catholic Schooling," Journal of Human Resources, 40 (4), 791-821.

Anderson, Kathryn, James Foster, and David Frisvold (2004) "Investing in Health: The LongTerm Impact of Head Start,” Vanderbilt University Working Paper 04-W26.

Anderson, Patricia M. and Kristin F. Butcher (2005) "Reading, Writing, and Raisinets: Are School Finances Contributing to Children’s Obesity?” NBER Working Paper 11177.

Averett, Susan and Sanders Korenman (1993) “The Economic Reality of the Beauty Myth,” NBER Working Paper 4521.

Bhattacharya, Jayanta, Janet Currie, and Steven Haider (2003) "Poverty, Food Insecurity, and Nutritional Outcomes in Children and Adults,” mimeo.

Bhattacharya, Jayanta, Janet Currie, and Steven Haider (2004) "Final Report: Evaluating the Impact of School Nutrition Programs,” Washington, D.C.: U.S. Department of Agriculture.

Birch, Leann L. (1999) “Development of Food Preferences,” Annual Review of Nutrition, 19, 4162.

Blau, David and Janet Currie (forthcoming) “Who’s Minding the Kids?: Preschool, Day Care, and After School Care,” in Finis Welch and Eric Hanushek (eds.) The Handbook of Education Economics, New York: North Holland.

Briley, Margaret E. and Cindy Roberts-Gray (1999) "Position of the American Dietetic Association: Nutrition Standards for Childcare Programs," Journal of the American Dietetic Association, 99 (8), 981-988.

Cawley, John (2000) “The Impact of Obesity on Wages,” Journal of Human Resources, 39 (2), 451-474.

Cole, Tim J., Mary C. Bellizzi, Katherine M. Flegal, and William H. Dietz (2000) "Establishing a Standard Definition for Child Overweight and Obesity Worldwide: International Survey," British Medical Journal, 320, 1240-

Chou, Shin-Yi, Michael Grossman, and Henry Saffer (2002) “An Economic Analysis of Adult Obesity: Results from the Behavioral Risk Factor Surveillance System,” NBER Working Paper 9247. 
Currie, Janet and Matthew Neidell (forthcoming) “Getting Inside the 'Black Box' of Head Start Quality: What Matters and What Doesn’t,” Economics of Education Review.

Currie, Janet and Duncan Thomas (1995) “Does Head Start Make a Difference?” American Economic Review, 85 (3), 341-364.

Currie, Janet and Duncan Thomas (2000) "School Quality and the Longer-Term Effects of Head Start,” Journal of Human Resources, 35 (4), 755-774.

Deckelbaum, Richard J. and Christine L. Williams (2001) "Childhood Obesity: The Health Issue,” Obesity Research, 9, 239S-243S.

Dehejia, Rajeev H. and Sadek Wahba (2002) "Propensity Score-Matching Methods for Nonexperimental Causal Studies,” Review of Economics and Statistics, 84 (1), 151-161.

Dietz, William H. (2001) "Breastfeeding May Help Prevent Childhood Overweight,” Journal of the American Medical Association, 285 (19), 2506-2507.

Dietz, William H. (2004) “Overweight in Childhood and Adolescence,” New England Journal of Medicine, 350 (9), 855-857.

Dietz, William H. and Steven L. Gortmaker (2001) "Preventing Obesity in Children and Adolescents,” Annual Review of Public Health, 22, 337-353.

Ebbeling, Cara B., Dorota B. Pawlak, and David S. Ludwig (2002) "Childhood Obesity: PublicHealth Crisis, Common Sense Cure,” Lancet, 360, 473-482.

Emerson, E. (2005) "Underweight, Obesity, and Exercise among Adults with Intellectual Disabilities in Supported Accommodation in Northern England,” Journal of Intellectual Disability Research, 49 (2), 134-143.

Felitti, Vincent J., Robert F. Anda, Dale Nordenberg, David F. Williamson, Alison M. Spitz, Valerie Edwards, Mary P. Koss, and James S. Marks (1998) "Relationship of Childhood Abuse and Household Dysfunction to Many of the Leading Causes of Death in Adults," American Journal of Preventive Medicine, 14 (4) 245-258.

Fontaine, Kevin R., David T. Redden, Chenxi Wang, Andrew O. Westfall, David B. Allison (2003) "Years of Life Lost Due to Obesity," Journal of the American Medical Association, 289 (2), 187-193.

Garces, Eliana, Duncan Thomas, and Janet Currie (2002) “Longer-Term Effects of Head Start," American Economic Review, 9 (4), 999-1012. 
Gordon, A., B. Devaney, and J. Burghardt (1995) "Dietary Effects of the National School Lunch Program and the School Breakfast Program,” American Journal of Clinical Nutrition, 61 (1), 221S-231S.

Gortmaker, Steven L., Karen Peterson, Jean Wiecha, Arthur M. Sobol, Sujata Dixit, Mary Kay Fox, and Nan Laird (1999) "Reducing Obesity via a School-Based Interdisciplinary Intervention Among Youth,” Archives of Pediatric and Adolescent Medicine, 153, 409-418.

Grossman, M., (1972) “On the Concept of Health Capital and the Demand for Health,” Journal of Political Economy, 80, 223-255.

Head Start Bureau (2004) Head Start Program Performance Standards and Other Regulations, Washington, DC: U.S. Department of Health and Human Services.

Head Start Bureau (2005) 2004 Head Start Program Fact Sheet, Washington, DC: U.S. Department of Health and Human Services.

Heckman, James J. (1999) “Policies to Foster Human Capital,” NBER Working Paper 7288.

Heckman, James J., Robert J. LaLonde, and Jeffrey A. Smith (1999) “The Economics and Econometrics of Active Labor Market Programs,” in O. Ashenfelter and D. Card (eds.) Handbook of Labor Economics, Vol. 3A, Amsterdam: Elsevier Science, 1865-2097.

Heckman, James J. and Dimitriy V. Masterov (2004) “The Productivity Argument for Investing in Young Children,” Working Paper 5, Invest in Kids Working Group, Committee for Economic Development.

Hofferth, Sandra L. and Sally Curtin (2005) “Poverty, Food Programs, and Childhood Obesity,” Journal of Policy Analysis and Management, 24 (4), 703-726.

James, Janet, Peter Thomas, David Cavan, and David Kerr (2004) “Preventing Childhood Obesity by Reducing Consumption of Carbonated Drinks: Cluster Randomised Controlled Trial,” British Medical Journal, 328, 1237-1243.

Keane, M.J., R.W. O’Brien, D.C. Connell, and N.C. Close (1996) A Descriptive Study of the Head Start Health Component, Washington, DC: U.S. Department of Health and Human Services.

Lamerz, Andreas, Jutta Kuepper-Nybelen, Nicole Bruning, Christine Wehle, Gabriele TrostBrinkhues, Hermann Brenner, Johannes Hebebrand, and Beate Herpertz-Dahlmann (2005) "Prevalence of Obesity, Binge Eating, and Night Eating in a Cross-Sectional Field Study of 6year-old Children and their Parents in a German Urban Population,” Journal of Child Psychology and Psychiatry, 46 (4), 385-393.

Ludwig, Jens and Douglas L. Miller (2005) “Does Head Start Improve Children’s Life Chances? Evidence from a Regression Discontinuity Design,” NBER Working Paper 11702. 
Maluccio, John A., John Hoddinott, Jere R. Behrman, Reynaldo Martorell, Agnes Quisumbing, and Aryeh D. Stein (2005) “The Impact of an Experimental Nutritional Intervention on Education into Adulthood in Rural Guatemala,” mimeo.

McKey, Ruth Hubbell, Larry Condelli, Harriet Ganson, Barbara J. Barrett, Catherine McConkey, Margaret C. Plantz (1985) The Impact of Head Start on Children, Families and Communities: Final Report of the Head Start Evaluation, Synthesis and Utilization Project, Washington, D.C.: CSR, Incorporated.

Morland, Kimberly, Steve Wing, and Ana Diez Roux (2002) “The Contextual Effect of the Local Food Environment on Residents’ Diets: The Atherosclerosis Risk in Communities Study,” American Journal of Public Health, 92 (11), 1761-1767.

Mrdjenovic, G. and D.A. Levitsky (2005) "Children eat what they are served: the Imprecise Regulation of Energy Intake,” Appetite, 44 (3), 273-282.

National Heart, Lung, and Blood Institute (1998) "Clinical guidelines on the identification, evaluation, and treatment of overweight and obesity in adults- the evidence report," Obesity Research, 6 (S2), 51S-209S.

Office of the Surgeon General (2001) “The Surgeon General’s Call to Action to Prevent Overweight and Obesity,” Rockville, MD: U.S. Department of Health and Human Services.

Ogden, Cynthia L., Richard P. Troiano, Ronette R. Breifel, Robert J. Kuczmarski, Katherine M. Flegal, and Clifford L. Johnson (1997) "Prevalence of Overweight Among Preschool Children in the United States, 1971 Through 1994,” Pediatrics, 99 (4), 1-7.

Peeters, Anna, Jan J. Barendregt, Frans Willekens, Johan P. Mackenbach, Abdullah Al Mamun, Luc Bonneux (2003) "Obesity in Adulthood and Its Consequences for Life Expectancy: A LifeTable Analysis,” Annals of Internal Medicine, 138, 24-32.

Rimmer, James H. and Edward Wang (2005) “Obesity Prevalence among a Group of Chicago Residents with Disabilities,” Archives of Physical Medicine and Rehabilitation, 86 (7), 14611464.

Ruhm, Christopher (2000) “Are Recessions Good For Your Health?” Quarterly Journal of Economics, 115 (2), 617-650.

Ruhm, Christopher (2005) “Healthy Living in Hard Times,” Journal of Health Economics, 24 (2), 341-363.

Staiger, Douglas and James H. Stock (1997) "Instrumental Variables Regression with Weak Instruments,” Econometrica, 65 (3), 557-586. 
Striegel-Moore, Ruth H., Christopher G. Fairburn, Denise E. Wilfley, Kathleen M. Pike, FaithAnne Dohm, and Helena C. Kraemer (2005) "Toward an Understanding of Risk Factors for Binge-Eating Disorder in Black and White Women: A Community-Based Case-Control Study," Psychological Medicine, 35, 907-917.

U.S. Department of Health and Human Services (2000) Healthy People 2010, Washington, DC: U.S. Government Printing Office.

U.S. Department of Health and Human Services, Administration for Children and Families (2005), Head Start Impact Study: First Year Findings, Washington, DC.

Variyam, Jayachandran N., James Blaylock, Biing-Hwan Lin, Katherine Ralston, and David Smallwood (1999) “Mother's Nutrition Knowledge and Children's Dietary Intakes,” American Journal of Agricultural Economics, 81 (2), 373-385.

Veugelers, Paul J. and Angela L. Fitzgerald (2005) "Effectiveness of School Programs in Preventing Childhood Obesity: A Multilevel Comparison,” American Journal of Public Health, 95 (3), 432-435.

Whitaker, RC, JA Wright, MS Pepe, KD Seidel, WH Dietz (1997) "Predicting Obesity in Young Adulthood from Childhood and Parental Obesity," New England Journal of Medicine, 337, 869873.

Wilde, Parke E., Paul E. McNamara, and Christine K. Ranney (2000) “The Effect on Dietary Quality of Participation in the Food Stamp and WIC Programs,” Washington, D.C.: U.S. Department of Agriculture.

Wolf, A. (1998) “What is the Economic Case for Treating Obesity?” Obesity Research, 6 (S1), 2S-7S.

Zenk, Shannon N., Amy J. Schulz, Barbara A. Israel, Sherman A. James, Shuming Bao, and Mark L. Wilson (2005) "Neighborhood Racial Composition, Neighborhood Poverty, and the Spatial Accessibility of Supermarkets in Metropolitan Detroit," American Journal of Public Health, 95 (4), 660-667. 
Table 1: Descriptive Statistics

\begin{tabular}{|c|c|c|c|c|c|}
\hline & All & Head Start & No Head Start & Black & White \\
\hline \multirow[t]{2}{*}{ Overweight } & 0.332 & 0.420 & 0.320 & 0.408 & 0.306 \\
\hline & [0.013] & [0.040] & [0.013] & [0.028] & [0.015] \\
\hline \multirow[t]{2}{*}{ Obese } & 0.144 & 0.189 & 0.137 & 0.193 & 0.127 \\
\hline & [0.010] & [0.032] & [0.010] & [0.022] & [0.011] \\
\hline \multirow[t]{2}{*}{ BMI } & 20.749 & 21.537 & 20.644 & 22.409 & 20.543 \\
\hline & [0.143] & [0.404] & [0.153] & [0.322] & [0.172] \\
\hline \multirow[t]{2}{*}{ Head Start } & 0.118 & 1.000 & 0.000 & 0.381 & 0.045 \\
\hline & [0.009] & & & [0.029] & [0.007] \\
\hline \multirow[t]{2}{*}{ Black } & 0.166 & 0.535 & 0.116 & 1.000 & 0.000 \\
\hline & [0.009] & [0.041] & [0.007] & & \\
\hline \multirow[t]{2}{*}{ Hispanic } & 0.075 & 0.128 & 0.068 & 0.000 & 0.000 \\
\hline & [0.008] & [0.031] & [0.008] & & \\
\hline \multirow[t]{2}{*}{ Other Race } & 0.055 & 0.068 & 0.053 & 0.000 & 0.000 \\
\hline & [0.007] & [0.025] & [0.007] & & \\
\hline \multirow[t]{2}{*}{ Birth Weight } & 119.864 & 119.230 & 119.948 & 112.655 & 121.700 \\
\hline & [0.532] & [1.694] & [0.559] & [1.133] & [0.632] \\
\hline \multirow[t]{2}{*}{ Oldest } & 0.349 & 0.242 & 0.364 & 0.296 & 0.366 \\
\hline & [0.013] & {$[0.030]$} & [0.014] & {$[0.024]$} & [0.015] \\
\hline \multirow[t]{2}{*}{ Disability } & 0.149 & 0.270 & 0.132 & 0.160 & 0.147 \\
\hline & [0.010] & [0.037] & [0.010] & [0.023] & [0.012] \\
\hline \multirow[t]{2}{*}{ Urban } & 0.381 & 0.313 & 0.390 & 0.451 & 0.329 \\
\hline & [0.013] & [0.035] & [0.014] & [0.027] & [0.015] \\
\hline \multirow[t]{2}{*}{ Rural } & 0.039 & 0.035 & 0.040 & 0.017 & 0.047 \\
\hline & {$[0.005]$} & {$[0.016]$} & [0.006] & {$[0.007]$} & [0.007] \\
\hline \multirow[t]{2}{*}{ Married } & 0.760 & 0.468 & 0.798 & 0.401 & 0.849 \\
\hline & [0.012] & {$[0.040]$} & [0.012] & {$[0.027]$} & {$[0.012]$} \\
\hline \multirow[t]{2}{*}{ Widowed } & 0.019 & 0.031 & 0.017 & 0.049 & 0.011 \\
\hline & [0.004] & [0.013] & [0.004] & {$[0.012]$} & [0.004] \\
\hline \multirow[t]{2}{*}{ Divorced } & 0.142 & 0.209 & 0.133 & 0.208 & 0.124 \\
\hline & [0.009] & {$[0.031]$} & [0.010] & {$[0.021]$} & {$[0.011]$} \\
\hline \multirow{2}{*}{ Family Income } & 60.061 & 23.178 & 64.983 & 30.902 & 69.654 \\
\hline & [1.309] & [1.313] & [1.420] & {$[1.376]$} & [1.659] \\
\hline \multirow[t]{2}{*}{ Family Size } & 4.206 & 4.478 & 4.170 & 4.320 & 4.145 \\
\hline & {$[0.031]$} & [0.119] & [0.031] & [0.093] & [0.032] \\
\hline \multirow[t]{2}{*}{ Father Not Present } & 0.234 & 0.593 & 0.186 & 0.629 & 0.1406 \\
\hline & [0.012] & [0.039] & [0.012] & {$[0.026]$} & [0.012] \\
\hline \multirow[t]{2}{*}{ Mother's Education } & 13.141 & 11.460 & 13.365 & 12.100 & 13.665 \\
\hline & {$[0.065]$} & {$[0.187]$} & [0.067] & {$[0.126]$} & [0.064] \\
\hline \multirow[t]{2}{*}{ Father's Education } & 13.070 & 11.129 & 13.330 & 11.612 & 13.694 \\
\hline & {$[0.070]$} & [0.154] & [0.073] & {$[0.124]$} & {$[0.073]$} \\
\hline Mother's BMI & 23.610 & 25.747 & 23.325 & 26.629 & 22.714 \\
\hline & {$[0.125]$} & [0.308] & [0.134] & [0.333] & [0.137] \\
\hline Father's BMI & 25.696 & 25.608 & 25.707 & 26.106 & 25.559 \\
\hline & [0.092] & {$[0.211]$} & {$[0.100]$} & [0.181] & [0.120] \\
\hline Female & 0.501 & 0.443 & 0.509 & 0.439 & 0.509 \\
\hline & {$[0.014]$} & [0.040] & [0.014] & {$[0.027]$} & {$[0.016]$} \\
\hline Age & 12.038 & 11.521 & 12.107 & 12.701 & 12.228 \\
\hline & [0.102] & {$[0.274]$} & [0.110] & [0.183] & {$[0.122]$} \\
\hline Relative Availability & 0.410 & 0.466 & 0.402 & 0.431 & 0.407 \\
\hline of Head Start & {$[0.006]$} & {$[0.018]$} & {$[0.006]$} & [0.013] & [0.007] \\
\hline Sample Size & 2301 & 414 & 1887 & 973 & 1138 \\
\hline
\end{tabular}

Notes: Weighted means with standard errors in brackets. The sample in the second column includes all children in the 2002

Child Development Supplement to the Panel Study of Income Dynamics (PSID) with information on Head Start attendance, body mass index, and county of residence at age 3 or 4 . The sample in the third and fourth columns is the subset of individuals who attended Head Start and who did not. The sample in the fifth and sixth columns is the subset of black and white individuals. See text or data appendix for further information about the definitions of these variables.

Sources: PSID, PSID Geocode file, Child Development Supplement to the PSID, Head Start Program Information Reports, and U.S. Census Bureau Small Area Income and Poverty Estimates 
Table 2: Probit Estimates of the Relationship between Head Start Participation and Overweight/Obesity

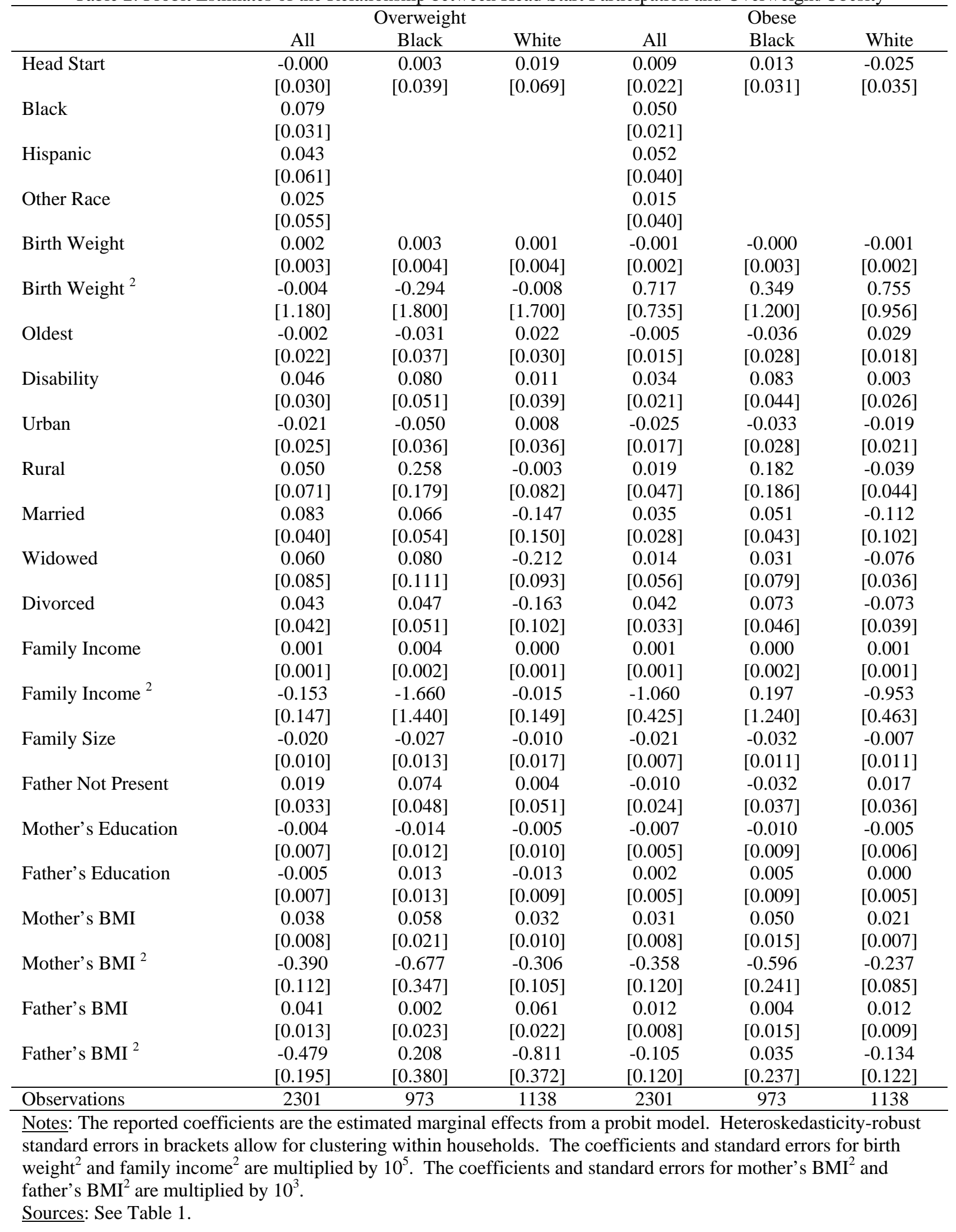


Table 3: Bivariate Probit Estimates of the Relationship between Head Start Participation and Overweight

\begin{tabular}{|c|c|c|c|c|c|c|}
\hline \multirow[b]{2}{*}{ Dependent Variable } & \multicolumn{2}{|c|}{ All } & \multicolumn{2}{|c|}{ Black } & \multicolumn{2}{|c|}{ White } \\
\hline & Head Start & Overweight & Head Start & Overweight & Head Start & Overweight \\
\hline ATT & \multicolumn{2}{|c|}{$\begin{array}{l}-0.249 \\
{[0.075]}\end{array}$} & \multicolumn{2}{|c|}{$\begin{array}{c}-0.334 \\
{[0.157]} \\
\end{array}$} & \multicolumn{2}{|c|}{$\begin{array}{c}-0.174 \\
{[0.220]}\end{array}$} \\
\hline Head Start & & $\begin{array}{l}-0.705 \\
{[0.223]}\end{array}$ & & $\begin{array}{l}-0.950 \\
{[0.471]}\end{array}$ & & $\begin{array}{l}-0.495 \\
{[0.659]}\end{array}$ \\
\hline $\begin{array}{l}\text { Relative Availability } \\
\text { of Head Start }\end{array}$ & $\begin{array}{c}0.772 \\
{[0.157]}\end{array}$ & & $\begin{array}{c}0.584 \\
{[0.185]}\end{array}$ & & $\begin{array}{c}1.582 \\
{[0.339]}\end{array}$ & \\
\hline Black & $\begin{array}{c}0.658 \\
{[0.107]}\end{array}$ & $\begin{array}{c}0.297 \\
{[0.085]}\end{array}$ & & & & \\
\hline Hispanic & $\begin{array}{c}0.245 \\
{[0.217]}\end{array}$ & $\begin{array}{c}0.071 \\
{[0.143]}\end{array}$ & & & & \\
\hline Other Race & $\begin{array}{c}0.286 \\
{[0.195]}\end{array}$ & $\begin{array}{c}0.144 \\
{[0.162]}\end{array}$ & & & & \\
\hline Birth Weight & $\begin{array}{l}-0.009 \\
{[0.007]}\end{array}$ & $\begin{array}{c}0.002 \\
{[0.007]}\end{array}$ & $\begin{array}{c}-0.013 \\
{[0.007]}\end{array}$ & $\begin{array}{c}0.002 \\
{[0.010]}\end{array}$ & $\begin{array}{l}-0.001 \\
{[0.018]}\end{array}$ & $\begin{array}{c}0.003 \\
{[0.012]}\end{array}$ \\
\hline Birth Weight $^{2}$ & $\begin{array}{c}0.051 \\
{[0.030]}\end{array}$ & $\begin{array}{c}0.008 \\
{[0.031]}\end{array}$ & $\begin{array}{c}0.066 \\
{[0.032]}\end{array}$ & $\begin{array}{c}0.015 \\
{[0.044]}\end{array}$ & $\begin{array}{c}0.012 \\
{[0.073]}\end{array}$ & $\begin{array}{c}0.001 \\
{[0.049]}\end{array}$ \\
\hline Oldest & $\begin{array}{c}0.146 \\
{[0.083]}\end{array}$ & $\begin{array}{c}0.011 \\
{[0.060]}\end{array}$ & $\begin{array}{c}0.159 \\
{[0.104]}\end{array}$ & $\begin{array}{l}-0.028 \\
{[0.096]}\end{array}$ & $\begin{array}{c}0.294 \\
{[0.194]}\end{array}$ & $\begin{array}{c}0.072 \\
{[0.087]}\end{array}$ \\
\hline Disability & $\begin{array}{c}0.530 \\
{[0.115]}\end{array}$ & $\begin{array}{c}0.195 \\
{[0.084]}\end{array}$ & $\begin{array}{c}0.431 \\
{[0.149]}\end{array}$ & $\begin{array}{c}0.291 \\
{[0.135]}\end{array}$ & $\begin{array}{c}0.799 \\
{[0.209]}\end{array}$ & $\begin{array}{c}0.071 \\
{[0.122]}\end{array}$ \\
\hline Urban & $\begin{array}{l}-0.069 \\
{[0.094]}\end{array}$ & $\begin{array}{l}-0.074 \\
{[0.067]}\end{array}$ & $\begin{array}{c}-0.084 \\
{[0.111]}\end{array}$ & $\begin{array}{l}-0.164 \\
{[0.093]}\end{array}$ & $\begin{array}{c}0.171 \\
{[0.209]}\end{array}$ & $\begin{array}{c}0.027 \\
{[0.104]}\end{array}$ \\
\hline Rural & $\begin{array}{l}-0.146 \\
{[0.261]}\end{array}$ & $\begin{array}{c}0.116 \\
{[0.201]}\end{array}$ & $\begin{array}{c}0.075 \\
{[0.461]}\end{array}$ & $\begin{array}{c}0.618 \\
{[0.485]}\end{array}$ & $\begin{array}{l}-0.622 \\
{[0.496]}\end{array}$ & $\begin{array}{l}-0.033 \\
{[0.245]}\end{array}$ \\
\hline Married & $\begin{array}{c}0.080 \\
{[0.125]}\end{array}$ & $\begin{array}{c}0.150 \\
{[0.111]}\end{array}$ & $\begin{array}{c}0.055 \\
{[0.142]}\end{array}$ & $\begin{array}{c}0.155 \\
{[0.136]}\end{array}$ & $\begin{array}{c}0.094 \\
{[0.449]}\end{array}$ & $\begin{array}{c}-0.434 \\
{[0.379]}\end{array}$ \\
\hline Widowed & $\begin{array}{c}-0.380 \\
{[0.210]}\end{array}$ & $\begin{array}{c}0.030 \\
{[0.214]}\end{array}$ & $\begin{array}{c}-0.229 \\
{[0.231]}\end{array}$ & $\begin{array}{c}0.105 \\
{[0.264]}\end{array}$ & $\begin{array}{c}-6.781 \\
{[0.439]}\end{array}$ & $\begin{array}{c}-0.907 \\
{[0.541]}\end{array}$ \\
\hline Divorced & $\begin{array}{l}-0.027 \\
{[0.129]}\end{array}$ & $\begin{array}{c}0.032 \\
{[0.109]}\end{array}$ & $\begin{array}{c}-0.085 \\
{[0.143]}\end{array}$ & $\begin{array}{c}0.059 \\
{[0.128]}\end{array}$ & $\begin{array}{l}-0.076 \\
{[0.487]}\end{array}$ & $\begin{array}{c}-0.564 \\
{[0.379]}\end{array}$ \\
\hline Family Income & $\begin{array}{c}-0.032 \\
{[0.003]}\end{array}$ & $\begin{array}{c}-0.001 \\
{[0.002]}\end{array}$ & $\begin{array}{c}-0.029 \\
{[0.012]}\end{array}$ & $\begin{array}{c}-0.003 \\
{[0.009]}\end{array}$ & $\begin{array}{c}-0.036 \\
{[0.007]}\end{array}$ & $\begin{array}{c}-0.001 \\
{[0.002]}\end{array}$ \\
\hline Family Income ${ }^{2}$ & $\begin{array}{c}0.050 \\
{[0.005]}\end{array}$ & $\begin{array}{c}0.001 \\
{[0.004]}\end{array}$ & $\begin{array}{c}0.000 \\
{[0.185]}\end{array}$ & $\begin{array}{c}0.014 \\
{[0.051]}\end{array}$ & $\begin{array}{c}0.058 \\
{[0.011]}\end{array}$ & $\begin{array}{c}0.001 \\
{[0.005]}\end{array}$ \\
\hline Family Size & $\begin{array}{c}0.109 \\
{[0.034]}\end{array}$ & $\begin{array}{c}-0.034 \\
{[0.027]}\end{array}$ & $\begin{array}{c}0.088 \\
{[0.037]}\end{array}$ & $\begin{array}{c}-0.034 \\
{[0.037]}\end{array}$ & $\begin{array}{c}0.213 \\
{[0.092]}\end{array}$ & $\begin{array}{c}-0.016 \\
{[0.052]}\end{array}$ \\
\hline Father Not Present & $\begin{array}{c}0.279 \\
{[0.102]}\end{array}$ & $\begin{array}{c}0.128 \\
{[0.090]}\end{array}$ & $\begin{array}{c}0.325 \\
{[0.123]}\end{array}$ & $\begin{array}{c}0.265 \\
{[0.126]}\end{array}$ & $\begin{array}{c}0.326 \\
{[0.243]}\end{array}$ & $\begin{array}{c}0.046 \\
{[0.152]}\end{array}$ \\
\hline Mother's Education & $\begin{array}{c}-0.042 \\
{[0.026]}\end{array}$ & $\begin{array}{c}-0.019 \\
{[0.018]}\end{array}$ & $\begin{array}{c}-0.042 \\
{[0.035]}\end{array}$ & $\begin{array}{l}-0.040 \\
{[0.027]}\end{array}$ & $\begin{array}{l}-0.035 \\
{[0.059]}\end{array}$ & $\begin{array}{l}-0.020 \\
{[0.029]}\end{array}$ \\
\hline Father's Education & $\begin{array}{c}0.007 \\
{[0.026]}\end{array}$ & $\begin{array}{c}-0.013 \\
{[0.019]}\end{array}$ & $\begin{array}{c}0.036 \\
{[0.035]}\end{array}$ & $\begin{array}{c}0.037 \\
{[0.031]}\end{array}$ & $\begin{array}{c}-0.036 \\
{[0.060]}\end{array}$ & $\begin{array}{c}-0.040 \\
{[0.027]}\end{array}$ \\
\hline Mother's BMI & $\begin{array}{c}0.108 \\
{[0.046]}\end{array}$ & $\begin{array}{c}0.108 \\
{[0.020]}\end{array}$ & $\begin{array}{c}0.125 \\
{[0.048]}\end{array}$ & $\begin{array}{c}0.167 \\
{[0.043]}\end{array}$ & $\begin{array}{c}0.070 \\
{[0.046]}\end{array}$ & $\begin{array}{c}0.092 \\
{[0.027]}\end{array}$ \\
\hline Mother's BMI $^{2}$ & $\begin{array}{c}-0.152 \\
{[0.075]}\end{array}$ & $\begin{array}{c}-0.112 \\
{[0.029]}\end{array}$ & $\begin{array}{c}-0.180 \\
{[0.073]}\end{array}$ & $\begin{array}{c}-0.203 \\
{[0.069]}\end{array}$ & $\begin{array}{l}-0.067 \\
{[0.053]}\end{array}$ & $\begin{array}{c}-0.089 \\
{[0.030]}\end{array}$ \\
\hline Father’s BMI & $\begin{array}{c}-0.116 \\
{[0.051]}\end{array}$ & $\begin{array}{c}0.088 \\
{[0.036]}\end{array}$ & $\begin{array}{c}-0.183 \\
{[0.066]}\end{array}$ & $\begin{array}{c}-0.047 \\
{[0.071]}\end{array}$ & $\begin{array}{c}0.083 \\
{[0.167]}\end{array}$ & $\begin{array}{c}0.167 \\
{[0.063]}\end{array}$ \\
\hline Father's BMI ${ }^{2}$ & $\begin{array}{c}0.132 \\
{[0.078]}\end{array}$ & $\begin{array}{c}-0.102 \\
{[0.055]}\end{array}$ & $\begin{array}{c}0.240 \\
{[0.100]}\end{array}$ & $\begin{array}{c}0.117 \\
{[0.111]}\end{array}$ & $\begin{array}{c}-0.211 \\
{[0.294]}\end{array}$ & $\begin{array}{c}-0.223 \\
{[0.103]}\end{array}$ \\
\hline Constant & $\begin{array}{l}-0.140 \\
{[1.094]}\end{array}$ & $\begin{array}{c}-3.886 \\
{[0.807]}\end{array}$ & $\begin{array}{c}1.252 \\
{[1.320]}\end{array}$ & $\begin{array}{l}-2.710 \\
{[1.609]}\end{array}$ & $\begin{array}{l}-3.420 \\
{[2.915]}\end{array}$ & $\begin{array}{c}-4.011 \\
{[1.337]}\end{array}$ \\
\hline$\rho$ & & & & & & \\
\hline Observations & & & & & & \\
\hline
\end{tabular}


Table 4: Bivariate Probit Estimates of the Relationship between Head Start Participation and Obesity

\begin{tabular}{|c|c|c|c|c|c|c|}
\hline \multirow[b]{2}{*}{ Dependent Variable } & \multicolumn{2}{|c|}{ All } & \multicolumn{2}{|c|}{ Black } & \multicolumn{2}{|c|}{ White } \\
\hline & Head Start & Obese & Head Start & Obese & Head Start & Obese \\
\hline ATT & \multicolumn{2}{|c|}{$\begin{array}{l}-0.089 \\
{[0.156]}\end{array}$} & \multicolumn{2}{|c|}{$\begin{array}{c}-0.332 \\
{[0.158]}\end{array}$} & \multicolumn{2}{|c|}{$\begin{array}{c}0.040 \\
{[0.351]}\end{array}$} \\
\hline Head Start & & $\begin{array}{c}-0.340 \\
{[0.606]}\end{array}$ & & $\begin{array}{l}-1.167 \\
{[0.491]}\end{array}$ & & $\begin{array}{c}0.142 \\
{[1.217]}\end{array}$ \\
\hline $\begin{array}{l}\text { Relative Availability } \\
\text { of Head Start }\end{array}$ & $\begin{array}{c}0.755 \\
{[0.166]}\end{array}$ & & $\begin{array}{c}0.563 \\
{[0.186]}\end{array}$ & & $\begin{array}{c}1.484 \\
{[0.349]}\end{array}$ & \\
\hline Black & $\begin{array}{c}0.671 \\
{[0.110]}\end{array}$ & $\begin{array}{c}0.268 \\
{[0.118]}\end{array}$ & & & & \\
\hline Hispanic & $\begin{array}{c}0.284 \\
{[0.201]}\end{array}$ & $\begin{array}{c}0.241 \\
{[0.177]}\end{array}$ & & & & \\
\hline Other Race & $\begin{array}{c}0.225 \\
{[0.224]}\end{array}$ & $\begin{array}{c}0.067 \\
{[0.178]}\end{array}$ & & & & \\
\hline Birth Weight & $\begin{array}{l}-0.009 \\
{[0.007]}\end{array}$ & $\begin{array}{l}-0.006 \\
{[0.008]}\end{array}$ & $\begin{array}{l}-0.013 \\
{[0.007]}\end{array}$ & $\begin{array}{c}-0.006 \\
{[0.009]}\end{array}$ & $\begin{array}{c}0.001 \\
{[0.019]}\end{array}$ & $\begin{array}{l}-0.006 \\
{[0.013]}\end{array}$ \\
\hline Birth Weight ${ }^{2}$ & $\begin{array}{c}0.050 \\
{[0.032]}\end{array}$ & $\begin{array}{c}0.036 \\
{[0.033]}\end{array}$ & $\begin{array}{c}0.000 \\
{[0.000]}\end{array}$ & $\begin{array}{c}0.000 \\
{[0.000]}\end{array}$ & $\begin{array}{c}-0.001 \\
{[0.075]}\end{array}$ & $\begin{array}{c}0.042 \\
{[0.054]}\end{array}$ \\
\hline Oldest & $\begin{array}{c}0.136 \\
{[0.085]}\end{array}$ & $\begin{array}{c}-0.013 \\
{[0.069]}\end{array}$ & $\begin{array}{c}0.156 \\
{[0.104]}\end{array}$ & $\begin{array}{c}-0.056 \\
{[0.104]}\end{array}$ & $\begin{array}{c}0.337 \\
{[0.208]}\end{array}$ & $\begin{array}{c}0.156 \\
{[0.106]}\end{array}$ \\
\hline Disability & $\begin{array}{c}0.531 \\
{[0.116]}\end{array}$ & $\begin{array}{c}0.188 \\
{[0.114]}\end{array}$ & $\begin{array}{c}0.422 \\
{[0.140]}\end{array}$ & $\begin{array}{c}0.379 \\
{[0.133]}\end{array}$ & $\begin{array}{c}0.818 \\
{[0.206]}\end{array}$ & $\begin{array}{l}-0.000 \\
{[0.163]}\end{array}$ \\
\hline Urban & $\begin{array}{l}-0.080 \\
{[0.097]}\end{array}$ & $\begin{array}{l}-0.121 \\
{[0.077]}\end{array}$ & $\begin{array}{l}-0.103 \\
{[0.114]}\end{array}$ & $\begin{array}{l}-0.160 \\
{[0.097]}\end{array}$ & $\begin{array}{c}0.184 \\
{[0.213]}\end{array}$ & $\begin{array}{l}-0.112 \\
{[0.120]}\end{array}$ \\
\hline Rural & $\begin{array}{l}-0.111 \\
{[0.277]}\end{array}$ & $\begin{array}{c}0.080 \\
{[0.215]}\end{array}$ & $\begin{array}{c}0.136 \\
{[0.481]}\end{array}$ & $\begin{array}{c}0.496 \\
{[0.489]}\end{array}$ & $\begin{array}{l}-0.512 \\
{[0.509]}\end{array}$ & $\begin{array}{l}-0.210 \\
{[0.246]}\end{array}$ \\
\hline Married & $\begin{array}{c}0.081 \\
{[0.126]}\end{array}$ & $\begin{array}{c}0.141 \\
{[0.133]}\end{array}$ & $\begin{array}{c}0.055 \\
{[0.145]}\end{array}$ & $\begin{array}{c}0.162 \\
{[0.143]}\end{array}$ & $\begin{array}{c}0.183 \\
{[0.507]}\end{array}$ & $\begin{array}{c}-0.501 \\
{[0.403]}\end{array}$ \\
\hline Widowed & $\begin{array}{l}-0.341 \\
{[0.210]}\end{array}$ & $\begin{array}{c}0.008 \\
{[0.244]}\end{array}$ & $\begin{array}{l}-0.255 \\
{[0.244]}\end{array}$ & $\begin{array}{c}-0.008 \\
{[0.233]}\end{array}$ & $\begin{array}{c}-6.931 \\
{[0.623]}\end{array}$ & $\begin{array}{c}-0.641 \\
{[0.600]}\end{array}$ \\
\hline Divorced & $\begin{array}{c}-0.017 \\
{[0.131]}\end{array}$ & $\begin{array}{c}0.145 \\
{[0.137]}\end{array}$ & $\begin{array}{c}-0.094 \\
{[0.143]}\end{array}$ & $\begin{array}{c}0.152 \\
{[0.150]}\end{array}$ & $\begin{array}{c}0.064 \\
{[0.537]}\end{array}$ & $\begin{array}{c}-0.525 \\
{[0.401]}\end{array}$ \\
\hline Family Income & $\begin{array}{c}-0.033 \\
{[0.003]}\end{array}$ & $\begin{array}{c}0.003 \\
{[0.007]}\end{array}$ & $\begin{array}{c}-0.029 \\
{[0.011]}\end{array}$ & $\begin{array}{c}-0.016 \\
{[0.010]}\end{array}$ & $\begin{array}{c}-0.038 \\
{[0.007]}\end{array}$ & $\begin{array}{c}0.008 \\
{[0.007]}\end{array}$ \\
\hline Family Income $^{2}$ & $\begin{array}{c}0.049 \\
{[0.006]}\end{array}$ & $\begin{array}{c}-0.030 \\
{[0.031]}\end{array}$ & $\begin{array}{c}0.000 \\
{[0.000]}\end{array}$ & $\begin{array}{c}0.000 \\
{[0.000]}\end{array}$ & $\begin{array}{c}0.060 \\
{[0.011]}\end{array}$ & $\begin{array}{l}-0.060 \\
{[0.035]}\end{array}$ \\
\hline Family Size & $\begin{array}{c}0.108 \\
{[0.034]}\end{array}$ & $\begin{array}{c}-0.082 \\
{[0.036]}\end{array}$ & $\begin{array}{c}0.085 \\
{[0.036]}\end{array}$ & $\begin{array}{c}-0.061 \\
{[0.052]}\end{array}$ & $\begin{array}{c}0.197 \\
{[0.092]}\end{array}$ & $\begin{array}{c}-0.046 \\
{[0.068]}\end{array}$ \\
\hline Father Not Present & $\begin{array}{c}0.269 \\
{[0.102]}\end{array}$ & $\begin{array}{c}-0.012 \\
{[0.115]}\end{array}$ & $\begin{array}{c}0.312 \\
{[0.119]}\end{array}$ & $\begin{array}{c}0.030 \\
{[0.143]}\end{array}$ & $\begin{array}{c}0.300 \\
{[0.240]}\end{array}$ & $\begin{array}{c}0.081 \\
{[0.196]}\end{array}$ \\
\hline Mother's Education & $\begin{array}{c}-0.041 \\
{[0.027]}\end{array}$ & $\begin{array}{c}-0.035 \\
{[0.023]}\end{array}$ & $\begin{array}{c}-0.053 \\
{[0.040]}\end{array}$ & $\begin{array}{c}-0.040 \\
{[0.031]}\end{array}$ & $\begin{array}{c}-0.014 \\
{[0.067]}\end{array}$ & $\begin{array}{c}-0.029 \\
{[0.037]}\end{array}$ \\
\hline Father's Education & $\begin{array}{c}0.009 \\
{[0.026]}\end{array}$ & $\begin{array}{c}0.011 \\
{[0.021]}\end{array}$ & $\begin{array}{c}0.043 \\
{[0.035]}\end{array}$ & $\begin{array}{c}0.028 \\
{[0.031]}\end{array}$ & $\begin{array}{c}-0.059 \\
{[0.068]}\end{array}$ & $\begin{array}{c}0.004 \\
{[0.030]}\end{array}$ \\
\hline Mother's BMI & $\begin{array}{c}0.105 \\
{[0.044]}\end{array}$ & $\begin{array}{c}0.141 \\
{[0.035]}\end{array}$ & $\begin{array}{c}0.111 \\
{[0.048]}\end{array}$ & $\begin{array}{c}0.195 \\
{[0.044]}\end{array}$ & $\begin{array}{c}0.057 \\
{[0.046]}\end{array}$ & $\begin{array}{c}0.116 \\
{[0.039]}\end{array}$ \\
\hline Mother's BMI ${ }^{2}$ & $\begin{array}{c}-0.148 \\
{[0.071]}\end{array}$ & $\begin{array}{c}-0.165 \\
{[0.054]}\end{array}$ & $\begin{array}{c}-0.002 \\
{[0.001]}\end{array}$ & $\begin{array}{c}-0.002 \\
{[0.001]}\end{array}$ & $\begin{array}{c}-0.051 \\
{[0.050]}\end{array}$ & $\begin{array}{c}-0.133 \\
{[0.049]}\end{array}$ \\
\hline Father’s BMI & $\begin{array}{c}-0.128 \\
{[0.051]}\end{array}$ & $\begin{array}{c}0.044 \\
{[0.041]}\end{array}$ & $\begin{array}{c}-0.184 \\
{[0.072]}\end{array}$ & $\begin{array}{c}-0.057 \\
{[0.070]}\end{array}$ & $\begin{array}{c}0.000 \\
{[0.190]}\end{array}$ & $\begin{array}{c}0.072 \\
{[0.051]}\end{array}$ \\
\hline Father's BMI ${ }^{2}$ & $\begin{array}{c}0.154 \\
{[0.075]}\end{array}$ & $\begin{array}{c}-0.034 \\
{[0.058]}\end{array}$ & $\begin{array}{c}0.002 \\
{[0.001]}\end{array}$ & $\begin{array}{c}0.001 \\
{[0.001]}\end{array}$ & $\begin{array}{c}-0.073 \\
{[0.321]}\end{array}$ & $\begin{array}{l}-0.078 \\
{[0.069]}\end{array}$ \\
\hline Constant & $\begin{array}{c}0.066 \\
{[1.066]}\end{array}$ & $\begin{array}{c}-3.709 \\
{[1.055]}\end{array}$ & $\begin{array}{c}1.625 \\
{[1.356]}\end{array}$ & $\begin{array}{c}-2.069 \\
{[1.876]}\end{array}$ & $\begin{array}{c}-2.013 \\
{[2.961]}\end{array}$ & $\begin{array}{c}-3.573 \\
{[1.355]}\end{array}$ \\
\hline$\rho$ & & & & & & \\
\hline Observations & & & & & & \\
\hline
\end{tabular}


Appendix Table 1: Linear IV Estimates of the Relationship between Head Start Participation and Overweight

\begin{tabular}{|c|c|c|c|c|c|c|}
\hline \multirow[b]{2}{*}{ Dependent Variable } & \multicolumn{2}{|c|}{ All } & \multicolumn{2}{|c|}{ Black } & \multicolumn{2}{|c|}{ White } \\
\hline & Head Start & Overweight & Head Start & Overweight & Head Start & Overweight \\
\hline Head Start & & $\begin{array}{l}-0.597 \\
{[0.344]}\end{array}$ & & $\begin{array}{l}-0.531 \\
{[0.445]}\end{array}$ & & $\begin{array}{l}-0.703 \\
{[0.584]}\end{array}$ \\
\hline $\begin{array}{c}\text { Relative Availability } \\
\text { of Head Start }\end{array}$ & $\begin{array}{c}0.151 \\
{[0.035]}\end{array}$ & & $\begin{array}{c}0.174 \\
{[0.059]}\end{array}$ & & $\begin{array}{c}0.119 \\
{[0.035]}\end{array}$ & \\
\hline Black & $\begin{array}{c}0.123 \\
{[0.021]}\end{array}$ & $\begin{array}{c}0.152 \\
{[0.051]}\end{array}$ & & & & \\
\hline Hispanic & $\begin{array}{c}0.045 \\
{[0.040]}\end{array}$ & $\begin{array}{c}0.063 \\
{[0.069]}\end{array}$ & & & & \\
\hline Other Race & $\begin{array}{c}0.007 \\
{[0.034]}\end{array}$ & $\begin{array}{c}0.028 \\
{[0.053]}\end{array}$ & & & & \\
\hline Birth Weight & $\begin{array}{l}-0.003 \\
{[0.002]}\end{array}$ & $\begin{array}{c}0.000 \\
{[0.003]}\end{array}$ & $\begin{array}{l}-0.005 \\
{[0.003]}\end{array}$ & $\begin{array}{c}-0.000 \\
{[0.004]}\end{array}$ & $\begin{array}{c}-0.001 \\
{[0.002]}\end{array}$ & $\begin{array}{c}0.001 \\
{[0.004]}\end{array}$ \\
\hline Birth Weight $^{2}$ & $\begin{array}{c}0.012 \\
{[0.008]}\end{array}$ & $\begin{array}{c}0.007 \\
{[0.012]}\end{array}$ & $\begin{array}{c}0.023 \\
{[0.012]}\end{array}$ & $\begin{array}{c}0.010 \\
{[0.020]}\end{array}$ & $\begin{array}{c}0.002 \\
{[0.008]}\end{array}$ & $\begin{array}{c}0.003 \\
{[0.018]}\end{array}$ \\
\hline Oldest & $\begin{array}{c}0.024 \\
{[0.016]}\end{array}$ & $\begin{array}{c}0.011 \\
{[0.025]}\end{array}$ & $\begin{array}{c}0.041 \\
{[0.031]}\end{array}$ & $\begin{array}{c}-0.004 \\
{[0.044]}\end{array}$ & $\begin{array}{c}0.019 \\
{[0.015]}\end{array}$ & $\begin{array}{c}0.031 \\
{[0.032]}\end{array}$ \\
\hline Disability & $\begin{array}{c}0.106 \\
{[0.025]}\end{array}$ & $\begin{array}{c}0.104 \\
{[0.048]}\end{array}$ & $\begin{array}{c}0.110 \\
{[0.049]}\end{array}$ & $\begin{array}{c}0.131 \\
{[0.073]}\end{array}$ & $\begin{array}{c}0.076 \\
{[0.026]}\end{array}$ & $\begin{array}{c}0.059 \\
{[0.060]}\end{array}$ \\
\hline Urban & $\begin{array}{c}-0.013 \\
{[0.018]}\end{array}$ & $\begin{array}{l}-0.036 \\
{[0.028]}\end{array}$ & $\begin{array}{c}-0.026 \\
{[0.033]}\end{array}$ & $\begin{array}{c}-0.072 \\
{[0.043]}\end{array}$ & $\begin{array}{c}0.014 \\
{[0.014]}\end{array}$ & $\begin{array}{c}0.010 \\
{[0.037]}\end{array}$ \\
\hline Rural & $\begin{array}{c}-0.028 \\
{[0.045]}\end{array}$ & $\begin{array}{c}0.037 \\
{[0.086]}\end{array}$ & $\begin{array}{c}0.023 \\
{[0.154]}\end{array}$ & $\begin{array}{c}0.255 \\
{[0.180]}\end{array}$ & $\begin{array}{l}-0.045 \\
{[0.040]}\end{array}$ & $\begin{array}{c}-0.032 \\
{[0.102]}\end{array}$ \\
\hline Married & $\begin{array}{c}-0.092 \\
{[0.038]}\end{array}$ & $\begin{array}{c}0.021 \\
{[0.058]}\end{array}$ & $\begin{array}{c}0.005 \\
{[0.047]}\end{array}$ & $\begin{array}{c}0.060 \\
{[0.057]}\end{array}$ & $\begin{array}{c}-0.065 \\
{[0.094]}\end{array}$ & $\begin{array}{c}-0.208 \\
{[0.155]}\end{array}$ \\
\hline Widowed & $\begin{array}{c}-0.157 \\
{[0.055]}\end{array}$ & $\begin{array}{c}-0.044 \\
{[0.104]}\end{array}$ & $\begin{array}{c}-0.063 \\
{[0.070]}\end{array}$ & $\begin{array}{c}0.028 \\
{[0.115]}\end{array}$ & $\begin{array}{c}-0.176 \\
{[0.096]}\end{array}$ & $\begin{array}{c}-0.425 \\
{[0.218]}\end{array}$ \\
\hline Divorced & $\begin{array}{c}-0.102 \\
{[0.039]}\end{array}$ & $\begin{array}{c}-0.026 \\
{[0.058]}\end{array}$ & $\begin{array}{c}-0.038 \\
{[0.048]}\end{array}$ & $\begin{array}{c}0.017 \\
{[0.055]}\end{array}$ & $\begin{array}{c}-0.059 \\
{[0.097]}\end{array}$ & $\begin{array}{c}-0.247 \\
{[0.156]}\end{array}$ \\
\hline Family Income & $\begin{array}{c}-0.003 \\
{[0.000]}\end{array}$ & $\begin{array}{c}-0.001 \\
{[0.001]}\end{array}$ & $\begin{array}{c}-0.012 \\
{[0.002]}\end{array}$ & $\begin{array}{l}-0.003 \\
{[0.006]}\end{array}$ & $\begin{array}{l}-0.001 \\
{[0.000]}\end{array}$ & $\begin{array}{l}-0.001 \\
{[0.001]}\end{array}$ \\
\hline Family Income ${ }^{2}$ & $\begin{array}{c}0.006 \\
{[0.001]}\end{array}$ & $\begin{array}{c}0.002 \\
{[0.002]}\end{array}$ & $\begin{array}{c}0.053 \\
{[0.010]}\end{array}$ & $\begin{array}{c}0.013 \\
{[0.028]}\end{array}$ & $\begin{array}{c}0.003 \\
{[0.001]}\end{array}$ & $\begin{array}{c}0.002 \\
{[0.002]}\end{array}$ \\
\hline Family Size & $\begin{array}{c}0.023 \\
{[0.008]}\end{array}$ & $\begin{array}{c}-0.005 \\
{[0.013]}\end{array}$ & $\begin{array}{c}0.026 \\
{[0.011]}\end{array}$ & $\begin{array}{c}-0.010 \\
{[0.017]}\end{array}$ & $\begin{array}{c}0.021 \\
{[0.011]}\end{array}$ & $\begin{array}{c}0.005 \\
{[0.021]}\end{array}$ \\
\hline Father Not Present & $\begin{array}{c}0.106 \\
{[0.024]}\end{array}$ & $\begin{array}{c}0.080 \\
{[0.051]}\end{array}$ & $\begin{array}{c}0.086 \\
{[0.036]}\end{array}$ & $\begin{array}{c}0.115 \\
{[0.063]}\end{array}$ & $\begin{array}{c}0.056 \\
{[0.032]}\end{array}$ & $\begin{array}{c}0.042 \\
{[0.065]}\end{array}$ \\
\hline Mother's Education & $\begin{array}{c}-0.009 \\
{[0.004]}\end{array}$ & $\begin{array}{c}-0.010 \\
{[0.008]}\end{array}$ & $\begin{array}{c}-0.007 \\
{[0.010]}\end{array}$ & $\begin{array}{c}-0.017 \\
{[0.012]}\end{array}$ & $\begin{array}{c}-0.007 \\
{[0.005]}\end{array}$ & $\begin{array}{c}-0.010 \\
{[0.011]}\end{array}$ \\
\hline Father's Education & $\begin{array}{c}0.002 \\
{[0.004]}\end{array}$ & $\begin{array}{c}-0.004 \\
{[0.007]}\end{array}$ & $\begin{array}{c}0.008 \\
{[0.009]}\end{array}$ & $\begin{array}{c}0.016 \\
{[0.013]}\end{array}$ & $\begin{array}{c}-0.007 \\
{[0.004]}\end{array}$ & $\begin{array}{c}-0.018 \\
{[0.010]}\end{array}$ \\
\hline Mother's BMI & $\begin{array}{c}0.013 \\
{[0.005]}\end{array}$ & $\begin{array}{c}0.043 \\
{[0.009]}\end{array}$ & $\begin{array}{c}0.033 \\
{[0.014]}\end{array}$ & $\begin{array}{c}0.069 \\
{[0.022]}\end{array}$ & $\begin{array}{c}0.005 \\
{[0.005]}\end{array}$ & $\begin{array}{c}0.034 \\
{[0.011]}\end{array}$ \\
\hline Mother's BMI $^{2}$ & $\begin{array}{c}-0.016 \\
{[0.008]}\end{array}$ & $\begin{array}{c}-0.045 \\
{[0.012]}\end{array}$ & $\begin{array}{c}-0.047 \\
{[0.022]}\end{array}$ & $\begin{array}{c}-0.084 \\
{[0.034]}\end{array}$ & $\begin{array}{c}-0.004 \\
{[0.005]}\end{array}$ & $\begin{array}{c}-0.032 \\
{[0.012]}\end{array}$ \\
\hline Father’s BMI & $\begin{array}{c}-0.026 \\
{[0.009]}\end{array}$ & $\begin{array}{c}0.023 \\
{[0.016]}\end{array}$ & $\begin{array}{c}-0.055 \\
{[0.023]}\end{array}$ & $\begin{array}{c}-0.020 \\
{[0.035]}\end{array}$ & $\begin{array}{c}-0.009 \\
{[0.006]}\end{array}$ & $\begin{array}{c}0.044 \\
{[0.013]}\end{array}$ \\
\hline Father's BMI ${ }^{2}$ & $\begin{array}{c}0.031 \\
{[0.012]}\end{array}$ & $\begin{array}{c}-0.025 \\
{[0.022]}\end{array}$ & $\begin{array}{c}0.073 \\
{[0.037]}\end{array}$ & $\begin{array}{c}0.046 \\
{[0.050]}\end{array}$ & $\begin{array}{c}0.009 \\
{[0.007]}\end{array}$ & $\begin{array}{c}-0.056 \\
{[0.016]}\end{array}$ \\
\hline Constant & $\begin{array}{c}0.588 \\
{[0.204]} \\
\end{array}$ & $\begin{array}{c}-0.691 \\
{[0.371]} \\
\end{array}$ & $\begin{array}{c}1.006 \\
{[0.426]}\end{array}$ & $\begin{array}{c}-0.466 \\
{[0.715]} \\
\end{array}$ & $\begin{array}{c}0.322 \\
{[0.190]} \\
\end{array}$ & $\begin{array}{c}-0.539 \\
{[0.443]} \\
\end{array}$ \\
\hline $\begin{array}{l}\text { F statistic of excluded } \\
\text { instrument }\end{array}$ & 18.32 & & 11.46 & & 8.62 & \\
\hline Observations & 2301 & 2301 & 973 & 973 & 1138 & 1138 \\
\hline $\begin{array}{l}\text { Notes: Heteroskedastic } \\
\text { the dependent variable } \\
\text { regressions with Relati } \\
\text { weight }^{2} \text { and family inc } \\
\text { multiplied by } 10^{2} \text {. } \\
\text { Sources: See Table } 1 \text {. }\end{array}$ & $\begin{array}{l}\text { standard erro } \\
\text { egressions. } \\
\text { ility of Head } \\
\text { nultiplied by }\end{array}$ & $\begin{array}{l}\text { brackets all } \\
\text { nns with Ov } \\
\text { t the exclude } \\
\text { The coeffici }\end{array}$ & $\begin{array}{l}\text { or clustering } \\
\text { ight as the } \\
\text { strument. T } \\
\text { and standar }\end{array}$ & $\begin{array}{l}\text { hin househ } \\
\text { dent varial } \\
\text { efficients a } \\
\text { ors for mot }\end{array}$ & $\begin{array}{l}\text { Columns wi } \\
\text { re instrument } \\
\text { tandard error } \\
\mathrm{BMI}^{2} \text { and } \mathrm{f}\end{array}$ & $\begin{array}{l}\text { Head Start as } \\
\text { ariables } \\
\text { r birth } \\
\text { r's BMI }{ }^{2} \text { are }\end{array}$ \\
\hline
\end{tabular}


Appendix Table 2: Linear IV Estimates of the Relationship between Head Start Participation and Obesity

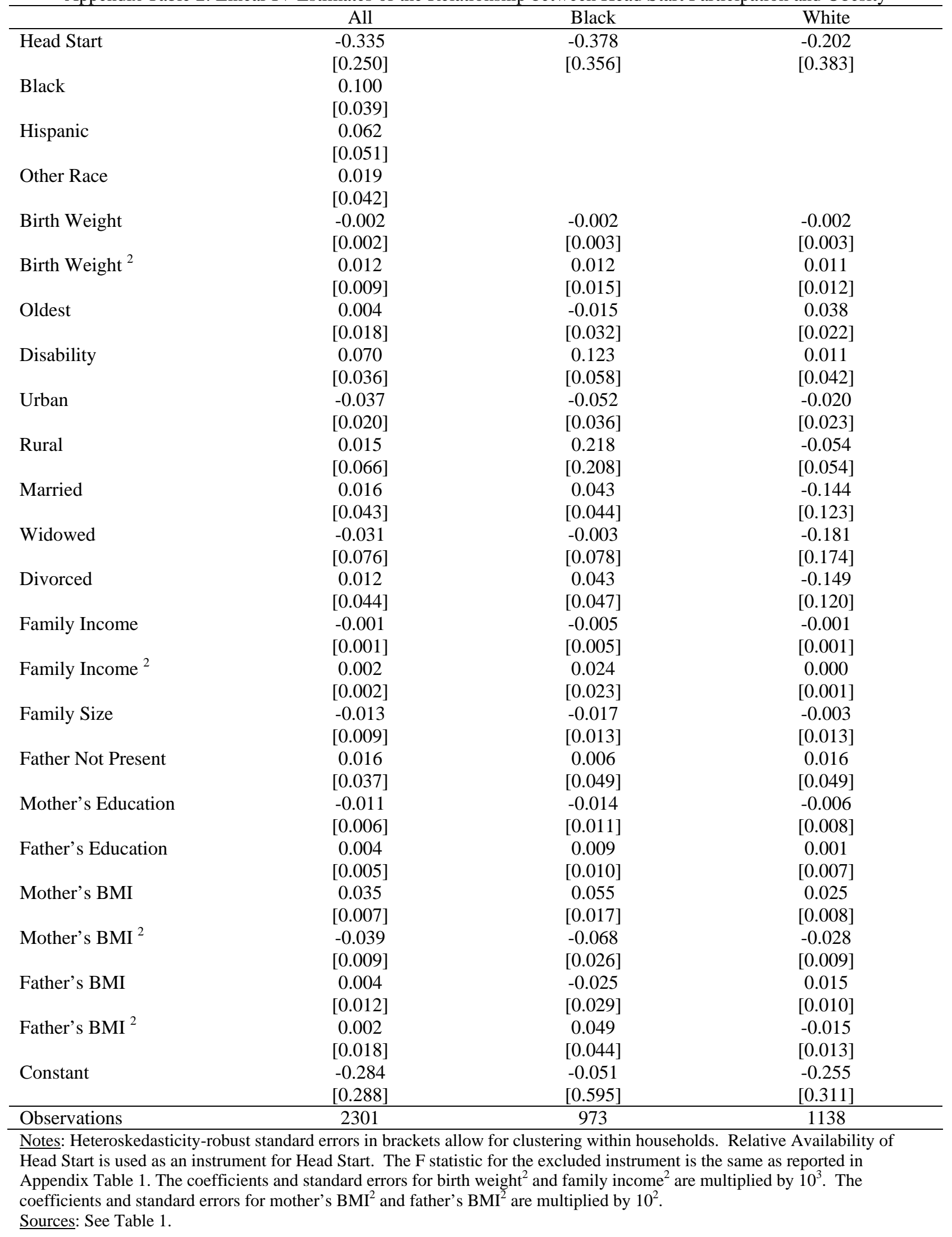




\section{Data Appendix}

This appendix provides a detailed explanation of the creation of variables used for this analysis.

Relative Availability of Head Start: The relative availability of Head Start is defined as the number of children who attend Head Start divided by number of eligible children in the local community. The local community is defined as the county or a group of counties commonly served by the same Head Start grantee(s). The regions that each grantee in each state served were obtained from the websites of the state's Head Start Association, the state's Head Start Collaboration Office, or through personal communication with a staff member in either of these groups.

The number of children who attend Head Start in each county in the U.S. is determined from the Head Start Program Information Reports, available from Xtria, from 1988 until 2001. These data are reported by each Head Start grantee annually. The number of children who actually attended the centers managed by each grantee is aggregated to the county level. Attendance figures from Early Head Start Centers and Parent Child Centers were not included because these centers served parents and children ages 0 through 3. American Indian/Alaskan Native programs and Migrant programs were also not included because these programs can have a much larger service region than other programs, and these programs serve a relatively small number of children. The address of each grantee is provided in the Program Information Reports, but not the county identifier. Each Head Start grantee was assigned a county code by linking the reported zip code with the Federal Information Processing Standards county codes using geographic data available from the Missouri Census Data Center. Remaining missing county codes were then determined based on the county of the grantee in other years, the county of the reported city, or by looking up the county that corresponds to the zip code using the Melissa Data Geocoder Lookup. The number of children who attend Head Start in each county was then aggregated to the service region to form the numerator in this variable.

The number of eligible children is derived from the Small Area Income and Poverty Estimates (SAIPE) of the U.S. Census Bureau. Eligibility is estimated based on poverty, which underestimates the true number of children eligible. However, at least 90 percent of children who attend Head Start in each program must be living in poverty, and measures of other eligibility criteria are not available annually for each county nationwide. In the SAIPE data, the number of children under age 5 in poverty is available for each state, but not for each county. For each county, the number of poor children under age 5 is the difference between the estimate of people ages 0 through 17 in poverty and the estimate of related children ages 5 through 17 in families in poverty. This difference is close to the number of children under age 5 in poverty, but is slightly incorrect because the figure for children ages 5 through 17 is based on related children in families. The degree to which this difference overestimates the number of poor children under age 5 is determined from the state level data. Each county estimate is then divided by this correction factor. The number of eligible children in each county is then defined as the number of children age 3 or 4 in poverty or two-fifths of the number of children under age 5 in poverty. County-level estimates are only available in 1989, 1993, and 1995-2001 from the SAIPE data. Estimates for the remaining years were determined through linear interpolation. The number of eligible children in each county was then aggregated to the service region to form the denominator in this variable. 
The number of children who attend Head Start is divided by the number of income eligible children for each service region and constrained to be greater than or equal to zero and less than or equal to one. This value represents the probability that an income eligible child will attend Head Start in the region before the selection decisions of the local Head Start administrators. This variable in then linked to Head Start attendance and other variables in the PSID by the county of residence, available from the restricted-access Geocode file of the PSID, and corresponding region code for each year between 1988 and 2001. The final value of this variable is then defined as the average number of children who attend Head Start divided by the number of income eligible children in the child's region of residence at ages 3 and 4 .

Some of the data used in this analysis are derived from Sensitive Data Files of the Panel Study of Income Dynamics, obtained under special contractual arrangements designed to protect the anonymity of respondents. These data are not available from the author. Persons interested in obtaining PSID Sensitive Data Files should contact the PSID staff through the Internet at PSIDHelp@isr.umich.edu.

Head Start: Determination of Head Start participation is based on three sets of questions asked of PSID and CDS respondents. In 1995, the responding family member was asked, for each individual ages 5 through 40 in the family, if each family member attended Head Start. In 1997, in the CDS, each primary caregiver was asked if the child participated in any intervention program, such as Head Start, Early Start (a family intervention program for children below age 7), or Fair Start (a Canadian child development program). Also, in the CDS in 1997, primary caregivers were asked about the childcare history, which included Head Start. In the CDS in 2002, primary caregivers were asked to update the childcare history from 1997 forward. For each question, Head Start participation was determined. For each of these questions about Head Start participation, possible sources of misreporting were corrected; the child was defined as having not participated in Head Start if participation began before age 2 (Early Head Start, not Head Start), if the family income - averaged across ages 3, 4, and 5 - was greater than twice the poverty line (adjusted for family size) and the child was not disabled, or if the child did not live in the U.S. at age 3 or 4 (Fair Start, not Head Start). Then Head Start participation was determined from the 1995 PSID question, the CDS intervention question, and the CDS childcare questions. If all three groups of questions agreed, then Head Start participation was easily determined. If two out of the three groups of questions agreed, then Head Start participation was coded based on the questions in agreement. If two out of the three groups of questions were missing, then Head Start participation was coded based on the non-missing question. The remaining cases were those in which no information was available from the 1995 question and the responses to the intervention and childcare questions differed. The responses to these questions could differ if the parent did not view Head Start to be a form of childcare, but instead a form of preschool or an intervention program, which would align the weighted response of Head Start participation with other reported estimates in the literature. These remaining cases were counted as participating in Head Start.

Overweight/Obese: Height and weight were measured by the CDS interviewer in 2002. Body mass index is then determined as weight in kilograms / (height in meters) ${ }^{2}$. Based on the ageand gender-specific cutoffs specified in Cole et al (2000), a child is defined as overweight (or obese) if their body mass index is greater than or equal to the appropriate threshold level. 
Race: Individuals are categorized as either white, black, Hispanic, or another race according to the reports of the primary caregiver in the CDS. A child's race is then specified by a set of binary variables for each racial group.

Birth weight: Birth weight in ounces is provided by the primary caregiver in the CDS.

Oldest: This dichotomous variable is equal to one if the child is the firstborn child of the mother.

Disability: This dichotomous variable is equal to one if the primary caregiver in the 1997 CDS reports that a doctor or health professional has ever said that the child had a speech impairment, hearing difficulty, difficulty seeing, retardation, emotional disturbance, orthopedic impairment, developmental delay, learning disability, or autism. This corresponds with the Head Start Bureau's definition of a disability.

Urban/Rural: Based on the Beale-Ross urban-rural codes from the 2001 PSID wave, residence is coded as urban if the family resides in a metropolitan area with a population of one million or more or a fringe county of such a metropolitan area. Residence in a rural location is coded dichotomously if, according to this categorization, the family's residence is completely rural.

Marital Status: Parents’ marital status is defined as married (including permanent cohabitation), divorced or separated, widowed, or single. A set of dichotomous variables are defined accordingly.

Family Income: Family income is defined as the total family income averaged over the years in which the child was 3, 4, and 5 years old. Total family income includes the taxable and transfer income of all household members. Income is converted into 2001 prices using the Consumer Price Index (for all urban consumers, the U.S. city average).

Family Size: Family size is defined as the total number of individuals in the family unit averaged over the years in which the child was 3,4 , and 5 years old.

Father Not Present: This dichotomous variable is defined as one if the father or a stepfather was not part of the family unit when the child was 3, 4, or 5 years old.

Parents' Education: These variables represent the years of schooling completed by the mother (female parental figure) and the father (male parental figure) averaged over the years in which the child was 3, 4, and 5 years old. The median years of schooling completed for each category were used to convert years of schooling into a continuous variable.

Parents' BMI: These variables are the body mass index of the child's mother (female parental figure) and father (male parental figure) in 1986. Height and weight are self-reported and then converted into body mass index using the formula: BMI = weight in kilograms / (height in meters) ${ }^{2}$. 